Curr Med Chem Anticancer Agents. 2004 January ; 4(1): 1-17.

\title{
Identification and Characterization of the Binding Sites of P- Glycoprotein for Multidrug Resistance-Related Drugs and Modulators
}

\author{
Ahmad R. Safa* \\ Department of Pharmacology and Toxicology and Indiana University Cancer Center, West Walnut \\ Street, Indianapolis, IN 46202
}

\begin{abstract}
A major problem in cancer treatment is the development of resistance to multiple chemotherapeutic agents in tumor cells. A major mechanism of this multidrug resistance (MDR) is overexpression of the $M D R 1$ product P-glycoprotein, known to bind to and transport a wide variety of agents. This review concentrates on the progress made toward understanding the role of this protein in MDR, identifying and characterizing the drug binding sites of P-glycoprotein, and modulating MDR by P-glycoprotein-specific inhibitors. Since our initial discovery that Pglycoprotein binds to vinblastine photoaffinity analogs, many P-glycoprotein-specific photoaffinity analogs have been developed and used to identify the particular domains of Pglycoprotein capable of interacting with these analogs and other P-glycoprotein substrates. Furthermore, significant advances have been made in delineating the drug binding sites of this protein by studying mutant P-glycoprotein. Photoaffinity labeling experiments and the use of sitedirected antibodies to several domains of this protein have allowed the localization of the general binding domains of some of the cytotoxic agents and MDR modulators on P-glycoprotein. Moreover, site-directed mutagenesis studies have identified the amino acids critical for the binding of some of these agents to P-glycoprotein. Furthermore, equilibrium binding assays using plasma membranes from MDR cells and radioactive drugs have aided our understanding of the modes of drug interactions with P-glycoprotein. Based on the available data, a topological model of Pglycoprotein and the approximate locations of its drug binding sites, as well as a proposed classification of multiple drug binding sites of this protein, is presented in this review.
\end{abstract}

\section{Keywords}

Photoaffinity labeling; multidrug resistance; P-glycoprotein; chemosensitizers

\section{INTRODUCTION}

Most metastatic cancers, as well as some hematological malignancies, are either intrinsically resistant to chemotherapy or acquire drug resistance subsequent to chemotherapy. Therefore, 
a major obstacle in cancer chemotherapy is the development of resistance to chemotherapeutic agents in tumor cells. It is well documented that several members of the large family of $\mathrm{ABC}$ transporters confer multidrug resistance (MDR) in human cancer cells. These transporters are three types of drug efflux pumps: the multidrug resistance gene 1 (MDR1 or ABCB1)-encoded P-glycoprotein, the multidrug resistance-associated protein (MRP1 or ABCC1), and breast cancer resistance protein (BCRP or ABCG2) [1-7]. These proteins may play an important part in the intrinsic or acquired defense of cells against a wide variety of drugs [1-7]. Recent studies have also shown the broad tissue distribution and drug substrate specificity of the seven MRP family members (MRP1-7; or ABCC1-6 and ABCC10) [3-5]. MRPs are multispecific organic anion transporters, which can transport negatively charged anionic drugs and neutral drugs conjugated to glutathione, glucuronate or sulfate [3-5]. However, the MDR1 P-glycoprotein transports a broad range of unmodified lipophilic agents, including a wide variety of drugs with different cellular targets, and confers resistance to such drugs by decreasing their intracellular concentrations $[8,9]$. Furthermore, P-glycoprotein is involved in limiting the oral bioavailability and tissue penetration of a variety of structurally divergent molecules. This review will concentrate on advances made over the last two decades in understanding the functional role of Pglycoprotein; identifying, characterizing, and localizing the drug-binding sites of Pglycoprotein structure; and applying this knowledge to identify potent P-glycoproteinspecific MDR modulators.

\section{P-GLYCOPROTEIN AND MDR}

Mammalian P-glycoprotein is encoded by a multigene family and divided into three classes: class I and II P-glycoproteins, which confer drug resistance, and class III, which does not [10]. The human class I P-glycoprotein encoded by the $M D R 1$ gene transports xenobiotics [9, 11], HIV protease inhibitors [12], steroids [13], immunosuppressants [14, 15], calcium cannel blockers [16], dopamine antagonists [17], peptides [18], phospholipids [19], and cholesterol [20]. In addition to increased expression during development of the MDR phenotype, P-glycoprotein is differentially expressed in normal tissues. We originally suggested that $\mathrm{P}$-glycoprotein serves as an anti-apoptotic protein [21]. More recent reports have shown that in addition to its role in inducing resistance to anticancer agents, $\mathrm{P}$ glycoprotein plays a general anti-apoptotic role, since cells overexpressing P-glycoprotein are resistant to a variety of apoptotic stimuli including serum starvation, Fas ligand, tumor necrosis factor, and UV-irradiation [22-28]. It is clear that P-glycoprotein has diverse functions in different cells and tissues; therefore, its expression is complex and highly regulated.

A very important concern in the treatment of human malignancies is intrinsic or acquired resistance to chemotherapy. Several reports have shown that overexpression of the MDR 1 gene is a negative prognostic factor in some solid tumors [29-33]. Recent results by Abolhoda et al. [32] clearly demonstrated rapid activation of $M D R 1$ gene expression in human metastatic sarcoma after in vivo exposure to doxorubicin. This latter study is particularly significant because it is the first analysis of transient induction of P-glycoprotein in solid tumors. One of the major limitations in the design of clinical trials correlating Pglycoprotein expression with the outcome of chemotherapy has been the time lag between 
the administration of chemotherapy and the determination of P-glycoprotein status. The best correlation between P-glycoprotein expression and unresponsiveness to chemotherapy has been demonstrated in hematological malignancies. These include acute myelogenous and lymphocytic leukemias (AML and ALL), multiple myeloma and non-Hodgkin's lymphoma [34]. Moreover, clinical studies have shown that the expression of P-glycoprotein in AML is a negative prognostic feature, particularly in the elderly [34-38]. Moreover, it has also been shown that overexpression of P-glycoprotein in hematological malignancies occurs more frequently at relapse than upon initial presentation [39].

\section{P-GP STRUCTURE AND FUNCTION}

The human P-glycoprotein is a 1280 amino acid membrane protein that confers resistance to a wide variety of structurally diverse anticancer agents by adenosine triphosphate (ATP)dependent efflux of these drugs across the plasma membrane [40-43]. This multidrug transporter is composed of two cassettes, and based on hydropathy plot analysis, each of the P-glycoprotein cassettes contain six putative transmembrane (TM) segments followed by a consensus nucleotide-binding domain (NBD). The two homologous cassettes are separated by an intracellular linker region of about 60 amino acid residues [40-44]. In addition to this model of P-glycoprotein, another model has been proposed, which consists of two membrane-embedded sixteen-strand $\beta$-barrels, connected by short loops to two six-helix bundles beneath each barrel $[45,46]$. The involvement of TM segments and NBDs in substrate recognition and ATP binding/hydrolysis, respectively, have been established [4752]. Substantial biochemical evidence, including changes in drug binding, epitope accessibility, fluorescent and spectroscopic measurements, and protease susceptibility [5359], suggests that TM segments undergo conformational change upon nucleotide binding. Pglycoprotein has high basal ATPase activity, and its ATPase activity can also be stimulated by drug binding [60-63]. in each cycle of ATP binding and hydrolysis, at least four conformations of P-glycoprotein (ligand-free, ATP-bound, ADP/Pi-bound after ATP hydrolysis, and ADP-bound) have been demonstrated [57]. Vanadate (V) can inhibit the drug (substrate)-inducible ATPase activity of P-glycoprotein by stably trapping the nucleoside diphosphate in the P-glycoprotein-ADP-bound/V conformation [64]. During the catalytic cycle of P-glycoprotein, although the transition state (P-ADP/Pi-bound/V) can be generated both via the hydrolysis of ATP and by directly providing ADP to the system, in the presence of substrate, the reaction is driven toward hydrolysis of ATP. Mechanistic details of the ATP hydrolytic cycle of MDR1 have significantly progressed over the last few years, and in the current model, both NBD's catalytic sites in MDR1 are active and ATP is hydrolyzed alternatively within the two sites. ATP hydrolysis at one site triggers conformational changes within P-glycoprotein resulting in drug transport, while at the other site, hydrolysis of a second ATP molecule is required for resetting the initial or high-affinity binding conformation. The two active sites act in a cooperative manner, and experiments support a model where the two ATP binding domains form a coupled catalytic machinery [65-67]. Recent evidence suggests that drugs alter the binding affinity to favor association of ATP with P-glycoprotein at the beginning of the catalytic cycle of the transport, and release of ADP from the transition state following nucleotide hydrolysis [68]. 
To understand the details of P-glycoprotein function, Rosenberg et al. $[69,70]$ reported the low to medium resolution structure of P-glycoprotein by single particle image analysis and electron crystallography of 2-dimensional (2-D) crystals. The 2-D projection maps of Pglycoprotein trapped at different stages of the hydrolytic cycle suggested that the TM segments form a chamber within the membrane that seems to be open to the extracellular milieu, and may also be accessible from the lipid phase at the interfaces between the two TM segments. These studies conclude that (1) nucleotide binding to P-glycoprotein causes a repacking of the TM segments and decreased drug binding affinity, therefore, ATP binding, not hydrolysis, drives the major conformational change associated with substrate translocation by P-glycoprotein, and (2) the distinct conformation of the protein was observed in the post-hydrolytic transition state prior to the release of ADP/P(i). The biochemical results suggest that these rearrangements may involve rotation of TM a-helices. These data are consistent with the recent results, comparing the 3-D structure of Pglycoprotein in the presence and absence of nucleotide. The results show that upon nucleotide binding, substantial conformational changes throughout the TM segments of Pglycoprotein occur, which require significant repacking of the transmembrane helices and opening a central pore along its length, potentially facilitating the transport of hydrophobic compounds from the lipid bilayer of the plasma membrane to the aqueous pore of the transporter.

Much effort has focused on identifying P-glycoprotein-specific pharmacological inhibitors to circumvent MDR. Several generations of P-glycoprotein-specific inhibitors have been developed to reverse P-glycoprotein-mediated MDR [71-74]. However, the major question is how P-glycoprotein interacts with such a large and diverse number of compounds. To answer this question, over the last several years, a major focus of research in many laboratories has been evaluating the functional role of P-glycoprotein as mediator of the MDR phenotype and its reversal by chemosensitizers (MDR modulators). In determining the biochemical basis of MDR, investigators have examined the relationship of P-glycoprotein drug-binding specificity to particular MDR phenotypic properties, such as drug uptake, efflux, accumulation, and MDR specificity. However, the molecular architecture of the drug binding sites, their exact location on the P-glycoprotein molecule, and the total number of the drug binding sites remain to be determined. Delineating the architecture of the drug binding sites of P-glycoprotein for both cytotoxic agents and the MDR modulators will be invaluable not only to understand how drugs interact with this protein, but also to design more useful and specific inhibitors of P-glycoprotein function. To identify and characterize P-glycoprotein drug-binding sites, several approaches have been employed including (1) equilibrium binding assays using radiolabeled P-glycoprotein-specific substrate and plasma membranes from drug resistant cells, (2) photoaffinity labeling experiments using photoaffinity analogs of both MDR-related agents and MDR modulators and Pglycoprotein-bearing cells or their plasma membranes, and (3) studying the naturally occurring mutant P-glycoproteins or site-directed mutations in the MDR1 gene, and analysis of the mutant P-glycoproteins with respect to their drug transport, drug binding and ATP hydrolysis capacity in the transfected cell lines compared to the wild-type protein. 


\section{PHOTOAFFINITY LABELING OF P-GP}

\section{A. Photoactive Analogs of Cytotoxic Agents}

While significant advances have been made in delineating the molecular mechanism of drug transport by P-glycoprotein, it is important to understand how the protein can bind to structurally diverse anticancer drugs, and to localize these sites and determine their relationship to the modulator binding sites. Over the last several years, a major focus of research in many laboratories has been to evaluate the functional role of P-glycoprotein as a mediator of the MDR phenotype and its reversal by modulators. The synthesis and use of radiolabeled photoactive analogs of cytotoxic agents and MDR modulators [75, 76] has allowed the identification of P-glycoprotein as a specific multidrug acceptor, thereby aiding our understanding of the functional role of this protein in MDR and its possible involvement in MDR reversal by P-glycoprotein modulators.

We initially explored the function of P-glycoprotein by synthesizing and using two photoaffinity analogs of vinblastine, one labeled with ${ }^{3} \mathrm{H}$ and one with ${ }^{125} \mathrm{I}$ [76]. Detailed procedures for the synthesis and use of these photoaffinity analogs as well as photoaffinity analogs of several cytotoxic agents and MDR modulators were recently published [75]. The structure of the vinblastine radioiodinated photoaffinity derivative $\mathrm{N}$-(p-azido-

$\left[3^{125} \mathrm{I}\right]$ salicyl)-N'-aminoethylvindesine ([$\left.\left.{ }^{125} \mathrm{I}\right] \mathrm{NASV}\right)$ [76] is presented in Fig. (1). Purified plasma membranes, mixed membranes vesicles, or intact cells were incubated with $\left[{ }^{125} \mathrm{I}\right] \mathrm{NASV}$ at $25^{\circ} \mathrm{C}$ for $15 \mathrm{~min}$ and then irradiated at $302 \mathrm{~nm}$ for $\left[{ }^{3} \mathrm{H}\right] \mathrm{NABV}$, or $366 \mathrm{~nm}$ for $\left[{ }^{125} \mathrm{I}\right] \mathrm{NASV}$, for $20 \mathrm{~min}$ to activate the analog. Polyacrylamide gel electrophoresis of solubilized photoaffinity labeled samples followed by autoradiography showed that $\left[{ }^{125}\right.$ I]NASV specifically bound only to P-glycoprotein in MDR cell lines [10, 77-80] (Fig. $2 \mathrm{~A}$ and B). Specific interaction of $\left[{ }^{125} \mathrm{I}\right] \mathrm{NASV}$ with P-glycoprotein in the MDR variants of the human lymphoblastic leukemia cell line CEM expressing 100-, 1000- and 5000-fold resistance to vinblastine (CEM/VBL100, CEM/VBL1000, and CEM/VBL5000) is shown in Fig, (2A). Evidence for the multidrug specificity of the Vinca alkaloid-binding site of Pglycoprotein has also been obtained [75, 79]. In the presence of $100 \mu \mathrm{M}$ of vinblastine, $\left[{ }^{125}\right.$ I]NASV photolabeling of P-glycoprotein in KB-3-1 epidermoid carcinoma cell line transfected with the $M D R 1$ gene (KB-GRC1 transfectants) was totally inhibited (Fig. 2B). Moreover, dactinomycin (actinomycin D), or doxorubicin partially inhibited [ $\left.{ }^{125} \mathrm{I}\right] \mathrm{NASV}$ photolabeling of P-glycoprotein in these cells (Fig. 2B). In contrast, colchicine, a drug to which the MDR cells are also cross-resistant, and methotrexate, a drug to which the MDR cells are sensitive, do not block vinblastine photolabeling of P-glycoprotein (Fig. 2B), suggesting that either colchicine binds to a separate site, or that it has lower affinity for the vinblastine binding site of P-glycoprotein. Similar results were obtained when other MDR cell lines were used in $\left[{ }^{125} \mathrm{I}\right] \mathrm{NASV}$ photolabeling experiments [10].

Since the original synthesis of the photoaffinity analogs of vinblastine, a number of photoaffinity analogs of MDR-related drugs have been synthesized [76]. Anthracyclines were poor inhibitors of P-glycoprotein photoaffinity labeling with the vinblastine photoaffinity analog (Fig. 2A) [79], suggesting that anthracyclines and Vinca alkaloids either have different binding affinities or separate binding sites on P-glycoprotein. 
Originally, Bushe et al. [81] demonstrated that high specific activity $\left[{ }^{125}\right.$ I]iodomycin, a Bolton-Hunter derivative of daunorubicin, which like daunorubicin is an inherently photoactive compound, can bind specifically to P-glycoprotein. The binding of $\left[{ }^{125}\right.$ I]iodomycin was inhibited by vinblastine $>$ daunorubicin $>$ colchicine $[81]$. We $[10,80]$ and others [82] have also used a ${ }^{3} \mathrm{H}$-labeled azidobenzoyl derivative of daunorubicin, $\mathrm{N}$-(pazido-[3, 5- $\left.{ }^{3} \mathrm{H}\right]$ benzoyl) daunorubicin $\left(\left[{ }^{3} \mathrm{H}\right] \mathrm{NABD}\right)$ (Fig. 1). We also have synthesized a tritiated photoaffinity analog of doxorubicin, $\mathrm{N}$-(p-azido-[3, $\left.5-{ }^{3} \mathrm{H}\right]$ benzoyl)doxorubicin $\left(\left[{ }^{3} \mathrm{H}\right] \mathrm{NAB}-\mathrm{DOX}\right)$ and a radioiodinated photoaffinity analog of daunorubicin, $\mathrm{N}$-(p-azido$\left[3-{ }^{125} \mathrm{I}\right]$ salicyl)daunorubicin ([125I]NAS-DNR) (Fig. 1), and found that these analogs bind specifically to P-glycoprotein ${ }^{\mathrm{a}}$ [80]. Photolabeling of P-glycoprotein with $\left[{ }^{3} \mathrm{H}\right] \mathrm{NAB}-\mathrm{DOX}$ was inhibited by cyclosporin A > vinblastine > NAB-DOX > and doxorubicin, respectively. Using [ ${ }^{125}$ I]NAS-DNR (Fig. 1), we have provided the first experimental confirmation that an amine group at C-3' is an important structural element of anthracyclines recognized by Pglycoprotein and that the hydroxyl group at C-14 (Fig. 1) might significantly affect the binding affinities of anthracyclines to P-glycoprotein ${ }^{\mathrm{a}}$.

While colchicine did not inhibit the binding of [ ${ }^{125}$ I]NASV (Fig. 2B), it is transported by Pglycoprotein $[76,79]$. To determine whether P-glycoprotein binds colchicines, we synthesized and used photoactive analogs of colchicine [83]. Both ${ }^{3} \mathrm{H}$-and ${ }^{125} \mathrm{I}$-labeled photoaffinity analogs bound specifically to P-glycoprotein [83]. The structure of the ${ }^{125} \mathrm{I}$ labeled photoaffinity analog $\mathrm{N}$-(p-azido-3- ${ }^{125} \mathrm{I}$-salicyl)-aminohexanoyldiacetylcolchicine ([ ${ }^{125}$ I]NASC) is shown in Fig. (1). Photolabeling of P-glycoprotein by $\left[{ }^{125}\right.$ I]NASC was inhibited by other compounds to which MDR cells are resistant in the following order: vinblastine $>$ vincristine $>$ doxorubicin $>$ dactinomycin (actinomycin D) $>$ colchicine [83]. These results and photoaffinity labeling experiments with [ ${ }^{125}$ I]NASV [18] and Fig. (2) suggest that vinblastine and colchicine may bind to separate sites, or that P-glycoprotein may have a common drug-acceptor site displaying high affinity for Vinca alkaloids and lower affinity for colchicine.

Photoactive analogs of other MDR-related drugs including rhodamine 123 (Rh 123), ${ }^{125} \mathrm{I}-$ labeled azidosalicyclic acid (ASA)-Rh 123 ([ $\left.{ }^{125} \mathrm{I}\right] \mathrm{ASA}-\mathrm{Rh} 123$ ) and benzimidazole (BZ) ([ ${ }^{125}$ I]ASA-BZ) (Fig. 1) have also been shown to specifically photolabel P-glycoprotein [84, 85]. Interestingly, vinblastine and verapamil, but not colchicine, inhibited the binding of these photoaffinity drugs to P-glycoprotein [85].

Paclitaxel is an excellent substrate for P-glycoprotein. To study the paclitaxel binding sites of P-glycoprotein, several photoaffinity analogs of paclitaxel have been synthesized and used [86]. Originally, a photoaffinity analog of paclitaxel bearing tritiated ${ }^{3} \mathrm{H}-\mathrm{p}$-benzoylhydrocinnamoyl (BzDC) was demonstrated to photolabel the mouse mdr1b P-glycoprotein (Fig. 1). Subsequently, two other analogs of paclitaxel bearing the tritium-labeled BzDC photophore at the 7 and 10 positions of paclitaxel likewise, specifically photoincorporated into mouse mdr1b P-glycoprotein [87]. The chemical structure of the 3'-BzDC paclitaxel photoaffinity analog is presented in Fig. (1). We $\mathrm{e}^{\mathrm{b}}$ recently synthesized a Taxol photoaffinity

\footnotetext{
aPriebe, W.; Przewloka, T.; Fokt, I.; Perez-Soler, R.; Safa, A.R. Amer. Assoc. Cancer Res., 1995, 36, 334 (Abst. 1989).

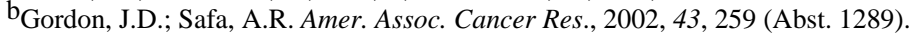


analog, N-(p-azido-[3,5- $\left.{ }^{125} \mathrm{I}\right]$ salicyl-3'-N-debenzoyl-Taxol ([ $\left.\left.{ }^{125} \mathrm{I}\right] \mathrm{NAST}\right)$, and used it to identify and characterize the Taxol binding sites of human P-glycoprotein. Photoaffinity labeling of P-glycoprotein in the multidrug resistant KB-V1 human cervical cancer cell line with [ ${ }^{125}$ I]NAST was inhibited by the MDR-related chemotherapeutic agents Taxol > vinblastine > vincristine > actinomycin, but not by doxorubicin. Moreover, P-glycoprotein photoaffinity labeling was very effectively inhibited by the MDR modulators PSC $833>$ cyclosporin A > cis-flupentixol > trans-flupentixol.

A P-glycoprotein-specific $\left[{ }^{3} \mathrm{H}\right]$-benzophenone photoaffinity analog of stipiamide, a new antibiotic effective in multidrug-resistant cancer cells, showed specific binding to human Pglycoprotein in the presence of cis-flupentixol, but not with cyclosporin A [88].

\section{B. Photoaffinity Analogs of MDR Modulators}

There has been major interest in developing strategies to circumvent MDR in vitro and ultimately in resistant tumor cells in patients. It is known that many diverse lipophilic agents enhance drug cytotoxicity in MDR cells. These agents possess many structural and chemical features common to chemotherapeutic drugs that bind to P-glycoprotein. To examine whether compounds known to reverse the MDR phenotype bind directly to P-glycoprotein, several photoaffinity analogs of the MDR modulators have been used. We initially used a photoaffinity analog of dihydropyridine, $\left[{ }^{3} \mathrm{H}\right]$ azidopine $[75,89]$ (Fig. 3), and provided the first experimental evidence that $\left[{ }^{3} \mathrm{H}\right]$ azidopine binds to $\mathrm{P}$-glycoprotein specifically $[76,89]$. In addition, $\left[{ }^{3} \mathrm{H}\right]$ azidopine photolabeling was partially blocked by verapamil and diltiazem, but was significantly stimulated by excess prenylamine and bepridil $[75,89]$. The stimulatory effect caused by prenylamine and bepridil may be a positive allosteric effect of these agents on $\left[{ }^{3} \mathrm{H}\right]$ azidopine labeling by binding to a separate site on P-glycoprotein and increasing the reversible binding of azidopine and its covalent coupling. The $\left[{ }^{3} \mathrm{H}\right]$ azidopine photolabeling of P-glycoprotein also was inhibited by excess vinblastine > actinomycin $\mathrm{D}>$ doxorubicin, demonstrating a broad P-glycoprotein drug recognition capacity [75, 89]. These data suggest a direct function for P-glycoprotein in the MDR.

To demonstrate directly that P-glycoprotein is a target for verapamil, we initially synthesized ${ }^{3} \mathrm{H}$ - and ${ }^{125} \mathrm{I}$-labeled photoaffinity analogs of verapamil $\left(\mathrm{N}\right.$-(p-azido-[3, 5- $\left.{ }^{3} \mathrm{H}\right]$ benzoyl)aminomethylverapamil $\left(\left[{ }^{3} \mathrm{H}\right] \mathrm{NAB}-\mathrm{VP}\right)$ and $\mathrm{N}$-(p-azido-3-

$\left[{ }^{125} \mathrm{I}\right]$ salicyl)aminomethylverapamil ([$\left.\left.{ }^{125} \mathrm{I}\right] \mathrm{NAS}-\mathrm{VP}\right)$ [90] (Fig. 3) and showed that they bind specifically to this protein $[76,90]$. Photoaffinity labeling of P-glycoprotein was inhibited in a dose-dependent manner by verapamil, vinblastine [90] and by other calcium channel blockers. Photolabeling was also partially inhibited by two of the drugs to which these cells are cross resistant, doxorubicin and actinomycin D [90]. Subsequently, Beck and Qian (91) using an optically pure photoaffinity analog of verapamil, LU-49888, reported similar results.

Since the demonstration of the specific photoaffinity labeling of P-glycoprotein with $\left[{ }^{3} \mathrm{H}\right]$ azidopine and verapamil photoaffinity analogs, several photoaffinity analogs of MDR modulators have been shown to specifically bind to P-glycoprotein. These photoaffinity analogs are B9209-005, an azido derivative of dexniguldipine [92], [ $\left.{ }^{125} \mathrm{I}\right]$ arylazidoprazosin ([ $\left.{ }^{125} \mathrm{I}\right]$ AAP) [93], N-(p-azido-3- ${ }^{125}$ I] iodophenethyl) spiperone ([ $\left.\left.{ }^{125} \mathrm{I}\right] \mathrm{NAPS}\right)$ [94] (Fig. 3) 
and radiolabeled photoaffinity analogs of synthetic isoprenoid [95], cyclosporin A [96], forskolin [97] and estramustine [98] (Figs. 3 and 4). Progesterone, [99] the synthetic progestin R5020 (promegestone) [80], and corticosterone [100] are also inherently photoactivatable and have been shown to bind to P-glycoprotein. Whether these compounds label similar or different sites on P-glycoprotein and whether they share closely related or separate sites with cytotoxic agents remain to be determined.

The pipecolinate derivative VX-710 (Biricodar) [101, 102] (Fig. 4) has been shown to modulate both P-glycoprotein 'as well as MRP functions. It reverses P-glycoproteinmediated MDR at concentrations of $0.5-2.5 \mu \mathrm{M}$ by direct interaction with P-glycoprotein and inhibition of its efflux activity [102]. Moreover, at $0.5-5 \mu \mathrm{M}$, it restored the sensitivity of HL-60/ADR cells known to express MRP1 to the cytotoxic action of doxorubicin, etoposide (VP16) and vincristine [101]. Consistent with these results, a photoaffinity analog

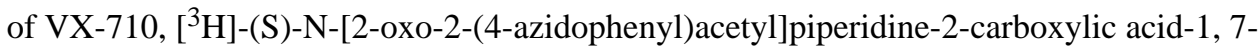
bis(3-pyridyl)-4-heptyl ester ([$\left.\left.{ }^{3} \mathrm{H}\right] \mathrm{VF}-13\right)[101,102]$ specifically photolabeled Pglycoprotein and MRP1 and VX-710 inhibited this binding in a concentration-dependent manner [101, 102]. This is the first photoaffinity analog of MDR modulators that binds to both P-glycoprotein [102] and MRP [101]. However, the efficiency of photolabeling of MRP by this photoprobe appears to be markedly less than its affinity for P-glycoprotein [101]. The combined reversal activity of VX-710 for both P-glycoprotein- and MRPmediated MDR mechanisms has made this agent suitable for clinical reversal of MDR [103].

\section{LOCALIZATION OF THE DRUG BINDING SITES OF P-GP}

\section{A. Photoaffinity Labeling and Domainal Mapping}

Many photoaffinity analogs of cytotoxic agents and MDR modulators have been developed in the last decade and have been used to study the drug binding sites of P-glycoprotein. However, the actual locations of photoincorporation of only a few P-glycoprotein specific analogs have been identified. Moreover, some of these binding sites (domains) have only been identified for mouse or Chinese hamster P-glycoprotein, and it is not known whether identical sites in human P-glycoprotein are labeled by the photoaffinity analogs. A topological model of P-glycoprotein and the approximate locations of its binding sites is presented in Fig. (5). Site-directed antibodies raised against various domains of Pglycoprotein have recognized the binding domains of this protein for $\left[{ }^{3} \mathrm{H}\right]$ azidopine, $\left[{ }^{125} \mathrm{I}\right] \mathrm{AAP}$ and a $\left[{ }^{125} \mathrm{I}\right]$-labeled photoactive analog of forskolin [104-106]. $\left[{ }^{3} \mathrm{H}\right]$ Azidopine and $\left[{ }^{125} \mathrm{I}\right] \mathrm{AAP}$ bind within or immediately C-terminal to TM segment 6 and TM segment 12 $[104,105]$, and the forskolin photoaffinity analog binds to TM segment 6 or to a region Cterminal to transmembrane (TM) segment 6 [106]. Recently, Demmer et al. demonstrated that labeling of Chinese hamster P-glycoprotein with [ $\left.{ }^{125} \mathrm{I}\right]$ iodomycin was restricted to amino acid residues 230-312, a region of the protein including TM segment 4, the second cytoplasmic loop, and part of TM segment 5 [107]. The results obtained by Wang et al. [108] using several fluorescent substrates of P-glycoprotein and P-glycoprotein inhibitors also support the assertion of two unequal substrate-binding sites that are allostericaily dependent on each other. More recently, using site-directed antibodies to several domains of human P-glycoprotein, and domainal mapping of the photoaffinity labeled protein, we found 
that $\left[{ }^{125} \mathrm{I}\right] \mathrm{NASV},\left[{ }^{125} \mathrm{I}\right] \mathrm{NAS}-\mathrm{VP},\left[{ }^{125} \mathrm{I}\right] \mathrm{NAPS}$ and azidopine bound to at least one common binding domain located within or immediately C-terminal to TM segment 6 of Pglycoprotein. However, kinetic analysis revealed that vinblastine and cyclosporin A competitively interact for the same binding site, while they noncompetitively interact with the azidopine-binding site $[109,110]$. Therefore, these results suggest that vinblastine and azidopine bind to separate binding sites on a common domain. Our data provide direct evidence that TM segment 6 is an important domain of P-glycoprotein for recognition of some MDR-related drugs and potent P-glycoprotein inhibitors.

Wu et al. [87], using a photoaffinity analog of paclitaxel bearing a 3'-BzDC group (Fig. 1) and domainal mapping using site-directed antibodies, showed that amino acid residues 9851088 of mouse mdr1b P-glycoprotein interact with this analog. This region includes half of the TM segment 12 and terminates just after the Walker A motif in the second nucleotide binding fold. Interestingly, another photoaffinity analog of paclitaxel with a 7-DzDC group incorporated into amino acid residues 683-760 of mouse P-glycoprotein, a region of the protein that includes TM segment 7 and half of TM segment 8 plus the intervening extracellular loop [87]. To localize the Taxol binding sites within P-glycoprotein, we $\mathrm{e}^{\mathrm{b}}$ produced site-directed antipeptideè antisera raised against ten different domains of $\mathrm{P}$ glycoprotein and used these antibodies to identify peptides containing the Taxol binding sites. In these experiments, [ $\left.{ }^{125} \mathrm{I}\right] \mathrm{NAST}$ photolabeled P-glycoprotein from KB-V1 was immunoprecipitated and then digested with $S$. aureus V8 protease. Maximum digestion with this protease revealed four major [ $\left.{ }^{125} \mathrm{I}\right] \mathrm{NAST}$-bound peptides, $12 \mathrm{kDa}, 10 \mathrm{kDa}, 8 \mathrm{kDa}$ and $6.5 \mathrm{kDa}$, which were immunoprecipitated using an antibody produced against amino acid residues $\mathrm{N}$-terminal to TM segment 3 . These peptides all seem to have a short five amino acid intercellular sequence in common, which is C-terminal to TM segment 4. Moreover, [ $\left.{ }^{125} \mathrm{I}\right] \mathrm{NAST}$ also bound to another $6.5 \mathrm{kDa}$ peptide, which was immunoprecipitated using an antibody produced against amino acid residues C-terminal to TM segment 6. Our data also suggest that the $6.5 \mathrm{kDa}$ Taxol binding domain C-terminal to TM segment 6 appears to overlap the vinblastine, verapamil, and azidopine-binding domain. These data indicate that regions $\mathrm{C}$-terminal to TM segment 4 and TM segment 6 appear to be a putative binding pocket for Taxol in human P-glycoprotein. These results compared with those reported by Wu et al. [87] as discussed above suggest that either Taxol may bind to different domains in mouse mdr1b P-glycoprotein compared to human P-glycoprotein, or that different photoaffinity analogs of Taxol may bind to non-identical domains. These results also suggest the possibility that different domains of P-glycoprotein may form a threedimensional arrangement of the drug binding sites. This idea is consistent with the finding that $\left[{ }^{125}\right.$ I]NAS-VP bound to two major 6.5 and $11 \mathrm{kDa}$ peptides and one minor $12 \mathrm{kDa}$ peptide within P-glycoprotein, while kinetic analysis of the binding of $\left[{ }^{125} \mathrm{I}\right] \mathrm{NAS}-\mathrm{VP}$ under equilibrium conditions to P-glycoprotein-bearing membrane vesicles showed a single high affinity binding site ${ }^{\mathrm{b}}$. These data suggest that spatially, these three $\left[{ }^{125} \mathrm{I}\right]$-bound peptides may form a single binding site. Based on these results, it is tempting to speculate that (1) the orientation of the photoactive group in the drug binding pocket determines which domain of $\mathrm{P}$-glycoprotein is labeled, and (2) P-glycoprotein substrates interact with distinct domains of the protein as a result of substantial conformational changes in the P-glycoprotein structure. In support of this latter hypothesis, different tertiary conformational changes take place upon 
the addition of MgATP and MgATP-verapamil, an MDR modulator that binds to and is actively transported by P-glycoprotein [111].

To evaluate the mechanism(s) of chemosensitization and identify the binding sites of dexniguldipine-HCI, Borchers et al. [112] used a tritium-labeled photoaffinity analog of dexniguldipine, $\left[{ }^{3} \mathrm{H}\right] \mathrm{B} 9209-005$, and photoaffinity labeled P-glycoprotein in the multidrug resistant T-lymphoblastoid cell line CCRF-ADR5000. After digestion with trypsin, the tryptic fragments were separated by high-performance liquid chromatography and analyzed by matrix-assisted laser desorption/ionization mass spectrometry (MALDI-MS). The MS results, corroborated by MALDI-MS of peptides after one step of Edman analysis, identified the $7 \mathrm{kDa}$ dexniguldipine-bound, tryptic P-glycoprotein peptide consisting of amino acid residues 468-527. This sequence region is flanked by the Walker motifs A and B of the $\mathrm{N}$ terminal ATP-binding cassette, suggesting direct interaction of dexniguldipine with the nucleotide-binding site of P-glycoprotein.

The presence of multiple drug binding sites on P-glycoprotein could potentially account for the wide variety of substrates known to interact with this protein. Several pharmacological studies measuring ATP hydrolysis and cellular drug accumulation indicate a multiplicity of drug interactions with P-glycoprotein [113-115]. Furthermore, our kinetic analysis of the binding of vinblastine and azidopine clearly demonstrated that these agents bind to separate sites and that cyclosporin A interacts competitively with vinblastine [109], but noncompetitively with the azidopine binding site [116]. Similarly, compounds, such as the indolizin sulfone SR33557 [114] and the 1, 4-dihydropyridines [116, 117] are able to confer allosteric control to the binding site on P-glycoprotein for the cytotoxic substrate vinblastine. These results provided direct evidence for multidrug binding sites within P-glycoprotein. Kinetic studies by Martin et al. [118] indicate that vinblastine and paclitaxel bind to separate sites within the P-glycoprotein structure and that dihydropyridine calcium channel blockers bind to a separate site distinct from the vinblastine and paclitaxel bind sites. Similarly, we have also confirmed by kinetic analysis that paclitaxel binds to a site different from that of vinblastine (Safa and Agresti, unpublished results). Particularly interesting, as shown in Fig. (6), we have demonstrated that P-glycoprotein may interact with some of its substrates stereoselectively. For instance, cis- and trans-flupentixol can reverse MDR, but cisfiupentixol increased the binding of [ $\left.{ }^{125} \mathrm{I}\right] \mathrm{AAP}$ to P-glycoprotein nine-fold more than transflupentixol [94]. However, both of these MDR reversing agents were potent inhibitors of [ ${ }^{125}$ I]NAPS [94], [ ${ }^{125}$ I]NASV, and [125I]NAS-VP binding to P-glycoprotein (Safa A. R. and Agresti M., unpublished data), suggesting their stereoselective effect on $\left[{ }^{125} \mathrm{I}\right] \mathrm{AAP}$ binding of P-glycoprotein. Several investigators have extended the multi-binding site model of Pglycoprotein. Ayesh et al. [113] and Shao et al. [119] proposed two separate binding sites, one for P-glycoprotein substrates, such as vinblastine, mefloquine and tamoxifen, and the other one for substrates such as verapamil. Similarly, verapamil and nicardipine display noncompetitive interaction with P-glycoprotein. In their model, cyclosporin A interacts with both sites [119]. A more complex model was proposed using a photoaffinity analog of 1, 4dihydropyridine [120]. Several chemosensitizer domains in P-glycoprotein, distinct from the Vinca alkaloid-binding site, were found using this photoaffinity probe. Garrigos et al. [121] demonstrated that vinblastine and verapamil could bind to P-glycoprotein either on different 
or overlapping sites. In contrast, vinblastine and progesterone bind to separate sites. However, the original report by Fleming et al. [122] suggested that vinblastine and the progesterone analog megestrol acetate (MA) may bind to the same site, but MA has a stimulatory effect on the binding of azidopine to P-glycoprotein. More recently, Shapiro et al. [123] have proposed a more complete view of the drug binding sites of P-glycoprotein. Their data support the existence of three drug-binding sites on P-glycoprotein. The $\mathrm{H}$ site is selective for Hoechst 33342 and colchicine. The R site is selective for rhodamine 123 and anthracyclines. The third binding site on P-glycoprotein has a positive allosteric effect on drug transport by the $\mathrm{H}$ and $\mathrm{R}$ sites. As Shapiro et al. [123] concluded, this allosteric site appears to be one of the sites of [125I]AAP photolabeling of P-glycoprotein originally reported by Safa et al. [93] and it may not be capable of drug transport [123].

We originally reported that progesterone may bind to the $\left[{ }^{125} \mathrm{I}\right] \mathrm{AAP}$ binding site of Pglycoprotein [93]. The results of Shapiro et al. [123] strongly support the idea that these two compounds bind to the third stimulatory allosteric site on P-glycoprotein and exert the same effect. The foregoing discussion fayors a multisite model of the P-glycoprotein drug binding sites originally proposed by Tamai and Safa [116] and Safa et al. [94], rather than a universal site model with broad substrate specificity as proposed by Borgnia et al. [124]. Martin et al. [118] employed radioligand-binding techniques to directly characterize drug interaction sites on P-glycoprotein and how these multiple sites interact. The drugs used were classified either as (1) substrates, which are known to be transported by P-glycoprotein (e.g., vinblastine) or (2) modulators, which alter P-glycoprotein function but are not themselves transported by the protein (e.g. XR9576). These authors demonstrated that drug interactions with P-glycoprotein were either competitive, at a common site, or noncompetitive, at distinct sites. Based on these data, they assign a minimum of four drug binding sites on P-glycoprotein. These sites fall into two categories: (1) transport sites, at which translocation of drug across the membrane can occur, and (2) regulatory sites, which alter P-glycoprotein function. However, some modulators interact with P-glycoprotein at a transport site rather than a regulatory site. Moreover, both transport and regulatory sites are able to switch between high- and low-affinity conformations. Interestingly, the multiple sites on P-glycoprotein display complex allosteric interactions through which binding of drug at one site switches other sites between high- or low-affinity conformations. Several issues, however, have not been well characterized, such as the number of the drug binding sites, their proximity and location, whether the sites for the cytotoxic substrates and those for modulators are entirely separate, and the manner in which these sites might influence each other.

We initially reported high and low affinity-binding sites for vincristine on P-glycoprotein [109]. Martin et al. [125] further determined whether substrate-binding sites on the Pglycoprotein undergo high- and low-affinity conformations in response to signals arising from nucleotide hydrolysis to effect active transport by this transporter. These authors used a radioligand binding assay to characterize the interaction of $\left[{ }^{3} \mathrm{H}\right]$ vinblastine with $\mathrm{P}$ glycoprotein and determine how drug binding site parameters are altered during a catalytic cycle of p-glycoprotein. In the absence of nucleotide, they showed that $\left[{ }^{3} \mathrm{H}\right]$ vinblastine interacts with a single class of binding site with high affinity. In the presence of the 
nonhydrolyzable ATP analog AMP-PNP, the drug binding site was in a low-affinity conformation. There was no alteration in the binding capacity, reflecting a complete shift in the high-affmity site to a low-affinity form. Their results suggest that alteration of the affinity of the vinblastine-binding site involves only one nucleotide-binding domain per transport cycle. The binding of ATP provides the signal to instigate this change, while release of phosphate post-ATP hydrolysis returns the transporter to its original state to complete the cycle.

It has also been proposed that P-glycoprotein substrates, hydrophobic peptides and MDR modulators interact with different overlapping regions of a large and flexible binding site, which is able to accommodate more than one substrate at a time [126]. However, this model does not explain the allosteric interaction of substrates with P-glycoprotein as previously discussed. Based on the kinetic analysis of binding of drugs to P-glycoprotein under equilibrium conditions, photoaffinity labeling experiments using various photoaffinity analogs of the cytotoxic agents and MDR modulators and competition experiments, as well as transport studies described above, seven binding sites are proposed for P-glycoprotein, which positively or negatively communicate with each other (Fig. 7). These are (1) the vinblastine binding site, which is shared with NAPS, verapamil (VP), and cyclosporin A (CsA), (2) the Taxoi binding site, (3) the binding site for dihydropyridine calcium channel blockers, (4) the binding site for the calcium channel blocker bepridil (BP), prenylamine, and megestrol acetate (MA), (5) the flupentixoi binding site, (6) IAAP binding site, and (7) the binding site for Hoechst 33342.

\section{B. Analysis of Mutations Affecting the Drug Binding Sites of P-Glycoprotein}

Considerable effort has been invested in characterizing drug resistance changes caused by Pglycoprotein mutations [52, 53, 127-145]. P-glycoprotein mutations that have appeared in cultured cells selected for resistance to particular drugs [130-132], and mutations incorporated by site-directed mutagenesis have been evaluated [52, 53, 127, 129, 134-145]. In many instances, as a result of a particular mutation, resistance to one drug may increase, while the resistance to other drugs may either remain the same or change. Mutation in a given amino acid may affect the protein's multiple functions, and in some instances, trying to correlate changes in drug resistance to altered drug binding can result in unexpected results. For instance, Choi et al. [130] demonstrated that the mutation G185 to V185 in human P-glycoprotein that arose during selection of colchicine resistant KB-3-1 cells causes increased colchicine resistance and decreased vinblastine resistance. However, we reported that this mutation causes a decrease in colchicine binding affinity and an increase in vinblastine binding affinity of P-glycoprotein in these cells [78].

There has been significant progress in defining the drug binding sites by site directed mutagenesis, obtaining cell lines with mutated P-glycoprotein and detecting alterations in the transport of a particular compound. The drug-binding sites of P-glycoprotein likely consist of residues from multiple TM segments. Mutational analysis has also shown that TM segment 5 and TM segment 6 in the N-terminal half, and TM segment 11 and TM segment 12 in the C-terminal half of P-glycoprotein, have an active role in drug transport and substrate specificity [134, 135, 138]. A domain-swapping study using the MDR1- 
glycoporotein and MDR2-P-glycoprotein showed that a domain including TM segment 11loop-TM segment 12 is important for drug transport [139]. Moreover, Loo and Clarke [140] performed cysteine-scanning mutagenesis of all the predicted TM segments of P-gp (TM segments $1-5$ and 7-10) and tested them for inhibition by a thiol-reactive substrate dibromobimane to identify residues within the drug-binding domain. The results of these studies, as well as those from site directed mutagenesis previously reported by these authors $[140,141]$, indicate that the drug-binding domain of P-glycoprotein consists of residues in TMs 4, 5, 6, 10, 11, and 12. Loo and Clarke [140] have also utilized cysteine-scanning mutagenesis to assess the interactions between the membrane spanning domains of human P-glycoprotein, and have proposed a model for the relative positioning of the membrane spanning domains of this protein and provide more insights into the drug binding domains of this protein. The results indicate that the TM segments 4,5 , and 6 are in proximity to TM segment 12, while TM segments 10,11, and 12 are in proximity to TM segment 6 . As concluded by these authors, TM segments critical for drug binding must be close to each other and exhibit different conformational changes in response to the binding of drug substrate. This arrangement supports previous work indicating that TM segments 4-6 and 10-12 are involved in drug binding [134, 136, 138]. These authors [129] also recently demonstrated that a P-glycoprotein deletion mutant (residues 1-379 plus 681-1025) with only the TM segments retained the ability to bindrhodamine. To identify the residues involved in rhodamine binding, Loo and Clark [129] generated mutants containing a cysteine in the predicted TM segments and reacted them with a thiol-reactive analog of rhodamine, methanethiosulfonate (MTS)-rhodamine. The activities of mutants in TM segments 6, 9, and 12 were significantly protected from inhibition by MTS-rhodamine by pretreatment with rhodamine $\mathrm{B}$, indicating that residues in these TM segments contribute to the binding of rhodamine dyes. Site-directed mutagenesis analysis of P-glycoprotein, in which point mutations in four amino acids clustered within a portion of the protein proposed to be located within transmembrane spanning domain 4 of mouse mdr1b P-glycoprotein caused complete loss of Taxol resistance due to each of the four mutations ${ }^{\mathrm{c}}$. These results are also supported our data that Taxol binds to regions C-terminal to TM segment 4 and TM segment 6 in human P-glycoprotein. Interestingly, deletion of a phenylalanine at amino acid residue 335 of P-glycoprotein (located in TM segment 6) has been shown to cause resistance to cyclosporin A and SDZ PSC 833 [142]. Furthermore, this mutation caused reduced photoaffinity labeling by cylosporin and azidopine [131]. Song and Melera [143] reported that actinomycin D resistant Chinese hamster variants expressing Pgpl with mutations in TM segments 9 and 6 are independently capable of conferring the same cross-resistance phenotype. Furthermore, the TM segment 6 mutations inhibit the ability of cyclosporin A to reverse cross-resistance and to block labeling of the protein by $\left[{ }^{125} \mathrm{I}\right]$ iodoarylazidoprazosin (IAAP), whereas the TM segment 9 mutations do not show similar effects. A chimeric protein containing both pairs of mutations confers twice the level of resistance to actinomycin $\mathrm{D}$ than that expected from the sum of the individual mutations, but it cannot be labeled to detectable levels with [125I]IAAP. Thus, TM segment 9 represents a site that cooperates with TM segment 6 to mediate drug resistance and [ ${ }^{125}$ I]IAAP labeling. Mutations in mouse mdr1b P-glycoprotein that alter the ability of steroids to act as either

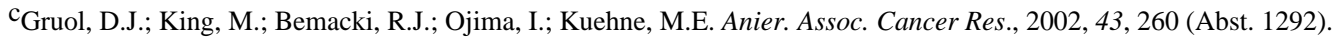


substrates or inhibitors have been shown to be confined to a small portion of the protein within TM segments 4, 5 and 6 [144]. However, the steroid interaction domain does not appear to overlap that of the Taxol interaction domain [145].

\section{PHARMACOLOGICAL REVERSAL OF MDR BY P-GLYCOPROTEIN- SPECIFIC INHIBITORS}

The clinical need to circumvent MDR has prompted major interest in searching for compounds capable of blocking P-glycoprotein function. A broad range of compounds that interact with P-gp and block drug efflux has been reported to reverse the MDR phenotype. Initially, Skovsgaard [146] examined the effect of relatively non-cytotoxic N-acetyldaunorubicin on the efflux of daunorubicin from resistant and sensitive Ehrlich ascites carcinoma cells, and demonstrated that adding this compound significantly increased the antitumor activity of daunorubicin in resistant tumors in vivo; however, no change was observed in the wild-type sensitive tumors. The impetus for identifying MDR modulators came from the work of Tsuruo et al. [147] showing that the calcium channel blocker verapamil reverses MDR. It is now known that a wide variety of lipophilic agents enhance drug cytotoxicity in MDR cells, possibly through interaction with P-glycoprotein [9, 10, 80, 81]. Many agents known to reverse MDR have been extensively reviewed [9, 94-96].

Many structurally distinct agents reverse multidrug resistance (MDR) by binding to Pglycoprotein and inhibiting the efflux of the MDR-related cytotoxic agents. However, the precise mechanism of how these agents interact with P-glycoprotein and reverse MDR is not well understood. The kinetics of the inhibition of P-glycoprotein is complex [74], and as discussed above, some of the drug binding sites can interact synergistically. On the basis of these synergies, in principle, P-glycoprotein inhibitors with increased affinity and specificity could be developed.

Several methods have been used to identify and assess the modulating effect of Pglycoprotein-specific MDR modulators. To investigate how the MDR-related cytotoxic agents bind to P-glycoprotein and are effluxed, and whether there is a direct relationship between MDR reversal and modulator interaction at the level of P-glycoprotein inhibition, we have used five approaches including (1) comparing the $\mathrm{IC}_{50}$ value (concentration which inhibits the growth of MDR cells by 50\%) for a cytotoxic drug in the absence and presence of relatively nontoxic concentrations of a modulator and determining "fold-sensitization", or "degree of potentiation" of the MDR modulator, (2) performing drug accumulation studies in drug senstive and MDR variants, (3) using photoaffinity analogs of the MDR-related cytotoxic agents and modulators, and identifying and characterizing their binding site by photoaffinity labeling, proteolytic digestion, and using P-glycoprotem epitope-specific antibodies, (4) inhibiting vinblastine, doxorubicin, verapamil and azidopine photolabeling of P-glycoprotein by a given MDR modulator, and (5) performing kinetic analysts and inhibition of binding of radioactive vinblastine and vincristine to plasma membrane vesicles under equilibrium conditions. Using these approaches, we [109] and others [114, 124, 153] have found that potent modulators ot relycoprotein interact either competitively or allosterically with the cytotoxic drug binding sites of P-glycoprotein and inhibit its function, 
thereby allowing the cytotoxic agent to accumulate in the MDR cells, inhibit growth, and cause cell death.

Understanding of the structural requirements of modulators of P-glycoprotein function should aid in the design of potent and specific therapeutic agents. While relative lipophilicity, the presence of a basic nitrogen atom and molecular refractivity have been suggested to be important factors for efficient interaction of an MDR reversing agent with Pglycoprotein $[154,155]$, the structural determinants or pharmacophore of chemically and pharmacologically diverse MDR modulators remain largely unknown. However, several reports have further defined important features of P-glycoprotein pharmacophore [156-166]. Recent structure-activity relationship studies ot P-glycoprotein substrates and modifiers indicate that if two substrates are applied simultaneously to P-glycoprotein, the compound with the higher potential to form hydrogen bonds generally acts as an inhibitor [159]. Moreover, based on this study, partitioning into the lipid membrane is the rate-limiting step for the interaction of a substrate with P-glycoprotein, and dissociation of the P-glycoprotein substrate complex is determined by the number and strength of the hydrogen bonds formed between the substrate and this multidrug transporter.

In support of this idea, Pajeva and Wiese [161] recently proposed a general pharmacophore model of P-glycoprotem drugs that is based on a highly diverse data set and relates to the verapamil-binding site of the protein. The pharmacophore model consists of two hydrophobic points, three hydrogen bond (HB) acceptor points, and one HB donor point. These authors concluded that the binding affinity of the drugs depends on the number of the pharmacophore points simultaneously involved in the interaction with P-glycoprotein. On the basis of their data, they proposed that (1) the verapamil binding site of P-glycoprotein has several points that can participate in hydrophobic and HB interactions, and (2) different drugs can interact with different receptor points in different binding modes. To have a better understanding of pharmacophore of the P-glycoprotein-specific substrates and inhibitors, Ekins et al. [164] built 3-dimensional quantitative structure activity relationship (3D-QSAR) models that qualitatively rank and predict $\mathrm{IC}_{50}$ values for P-glycoprotein inhibitors. These models were derived and tested with data for inhibition of vinblastine accumulation, vinblastine binding, digoxin transport, and calcein accumulation. This study predicted 16 inhibitors of verapamil binding to P-glycoprotein using these models. These inhibition results were then used to generate a new pharmacophore that consisted of one hydrogen bond acceptor, one ring aromatic feature, and two hydrophobes. The degree of similarity in rank ordering prediction by these inhibitor pharmacophore models confirmed that verapamil, vinblastine, and digoxin are likely to bind the same or overlapping sites within Pglycoprotein. Important features on these substrates include multiple hydrophobic and hydrogen bond acceptor characteristics, which are widely dispersed and in agreement among most of the other inhibitor pharmacophores reported [165]. These 3D-QSAR models will be useful for future prediction of likely substrates and inhibitors of P-glycoprotein. Garrigues et al. [166] combined affinities and mutual relationships from the changes in P-glycoprotein ATPase activity induced by actinomycin D and a series of cyclic peptides and peptide-like compounds, used alone or in combination with a molecular modeling approach, and superimposed the three-dimensional hydrophobic and polar elements of these molecules. 
The results of this study made it possible to characterize two different types of pharmacophores in the P-glycoprotein, which appear to be composed of several specific sites located close together. Furthermore, the results indicate that the binding of drugs to Pglycoprotein is governed by the distribution of their hydrophobic and polar elements rather than by their chemical motifs.

The MDR modulators can be divided into two groups: (1) those which only bind to Pglycoprotein and block the binding and transport of MDR-related cytotoxic agents, but which are not effluxed (e.g., progesterone, XR9576, and LY335979) [167-169], and (2) those which block the binding of MDR-related drugs and are also effluxed from MDR cells. These latter modulators compete for outward transport of the MDR-related drugs (e.g. cyclosporin A, FK-506, azidopine I-NAPS, and ivermectin) [94,116,170,171].

Three generations of P-glycoprotein-specific MDR modulators have been developed. The first generation modulators consisted of calcium channel blockers, calmodulin inhibitors, cardiovascular drugs, hormonal/steroidal derivatives antibiotics, the cyclosporins, and other miscellaneous compounds [9, 94-96]. These compounds were not specifically developed for modulation of MDR and had other pharmacological applications. While these compounds were substrates for P-glycoprotein, they were relatively weak MDR modulators. Furthermore, major toxicities associated with most of these compounds at the required concentrations to inhibit P-glycoprotein activity have prevented their widespread clinical use [172-175]. The requirement for more specific and potent P-glycoprotein inhibitors as MDR modulators has led to the development of second-generation modulators, such as the nonimmunosuppressive cyclosporin D analogue PSC 833 (Valspodar) [176], VX-710 (Biricodar) [102], the acridone carboxamide derivative GF120918 (GG918) [177] and the diketopiperazine derivative XR9051 [178]. Clinical trials have demonstrated some clinical benefit from the use of modulators such as PSC $833[179,180]$. However, VX-710 and PSC 833 have shown significant enhancement of the pharmacokinetics and toxicity cytotoxic agents such as paclitaxel, and doxorubicin, which has necessitated reduction of the cytotoxic drug dose when administered with these modulators [181-183]. The third generation MDR modulators have been designed because of the need for compounds lacking other pharmacological effects, which thereby confer greater selectivity and specificity for Pglycoprotein. These modulators include LY335979 [168], R101933 [184] and XR9576 (Tariquidar) [184], which are the more potent and specific P-glycoprotein modulators. Drug binding experiments and kinetic analysis have shown that XR9576 inhibits P-glycoprotein function by binding at a modulatory site, which is distinct from the site of interaction of Pglycoprotein substrates [185]. The two sites may be classified as serving modulatory or transport functions [185]. Animal studies have shown that XR9576, and LY335979 exhibit no significant pharmacokinetic interaction with doxorubicin, etoposide, and paclitaxel in animal studies [168, 169, 186, 187]. Therefore, these studies indicate that the development of potent and specific P-glycoprotein inhibitors is an important approach to reversing MDR in the clinic of co-administered drugs.

Recent studies have used 99mTc-sestamibi, a substrate of P-glycoprotein, as a functional imaging agent for the P-glycoprotein-mediated MDR phenotype [188, 189]. Retention of $99 \mathrm{mTc}$-sestamibi by cells that overexpress P-glycoprotein can be enhanced by the addition 
of P-glycoprotein inhibitors. Recent reports have shown enhanced sestamibi retention in imaged tumors in a subset of patients treated with the third generation P-glycoproteinspeciflc MDR modulators [73, 191, 192]. These results suggest that potent and selective Pglycoprotein modulators can increase drug accumulation in P-glycoprotein-expressing tumors. As noted above, since these agents exhibit no significant pharmacokinetic interaction with the MDR-related chemotherapeutic agents, using third generation Pglycoprotein inhibitors and properly designed clinical trials, it should be possible to determine the contribution of modulators to the reversal of clinical drug resistance.

Several strategies may be used to achieve maximum modulation of P-glycbprotein-related MDR in vitro and some of these strategies can be applicable to the clinical reversal of MDR. These strategies include: (1) using P-glycoprotein substrate competitive inhibitors (e.g. cyclosporin A is a competitive inhibitor of vinblastine binding to P-glycoprotein), (2) using substrates of P-glycoprotein that can bind to the protein and allosterically inhibit binding of cytotoxic agents (e.g. azidopine is a noncompetitive inhibitor of vinblastine binding to Pglycoprotein), (3) using a combination of competitive and allosteric inhibitors of Pglycoprotein, (4) utilizing membrane active agents that disrupt P-glycoprotein interaction with membrane lipid (e.g. lipid fluidizers), (5) using cytotoxic drugs that are not transported by P-glycoprotein (e.g. morpholinoanthracyclines), (6) utilizing compounds, which downregulate P-glycoprotein expression, (7) using agents that prevent P-glycoprotein induction (e.g. protein kinase inhibitors), (8) utilizing anti-P-glycoprotein antibodies with MDR modulators, (9) modifying the delivery of MDR drugs (e.g. liposome encapsulation), (10) using antisense oligonucleotides to prevent P-glycoprotein expression, and (11) taking advantage of the use of agents to which MDR cells are collaterally sensitive. The use of two modulators with different toxicities may produce an additive or synergistic effect in modulating MDR at lower and safer concentrations ${ }^{\mathrm{d}}$. Simultaneous use of two modulators, one acting competitively and the other acting noncompetitively, with the cytotoxic drug for binding to P-glycoprotein is an attractive approach, and we have previously shown that combinations of two MDR modulators, cyclosporin A and tamoxifen, synergistically enhances the cytotoxicity of vinblastine in a P-glycoprotein-containing cell lined ${ }^{\mathrm{d}}$.

Cytotoxic agents, which are not substrates for P-glycoprotein and therefore, unable to be effluxed from the MDR cells, have been shown to be effective in both sensitive cells and their P-glycoprotein expressing cells [193]. For example, it has been shown that the amino group at the C-3' position of doxorubicin is an important determinant of anthracycline binding to P-glycoprotein [193, 194]. Hydroxyrubicin, an analog of doxorubicin, which has a hydroxyl group at C-3', was shown to have very poor affinity for P-glycoprotein in photoaffinity labeling experiments, and increased activity against MDR cells [194]. Lampidis et al. [193], using a selected series of analogs in which lipophilicity and/or positive charge were altered, found that positively charged anthracyclines are better recognized by P-glycoprotein positive cells compared to their natural counterparts, and with increasing lipophilicity, charge becomes less important for P-glycoprotein recognition. Interestingly, photoaffinity analysis suggested that the highly lipophilic anthracycline

d Samuels, B.I.; Murray, J.L.; Safa, A.R. Amer. Assoc. Cancer Res., 1990, 31, 361 (Abst. 2138). 
analogs, regardless of charge, prevent $\left[{ }^{125} \mathrm{I}\right] \mathrm{NAS}$-VP binding to P-glycoprotein. Consistent with these results, in MDR cells with a resistance index to doxorubicin of 4, 534, as compared to parental cells, almost all of the resistance is circumvented (resistance index $=3$ ) with an anthracycline that does not contain a protonatable nitrogen and is highly lipophilic (partition coefficient, $\log p>1.99$ ). As lipophilicity is increased to $\log p>1.99$ and nuclear binding is decreased, anthracycline localization switches from nuclear to cytoplasmic, which most likely indicates a different cytotoxic target and mechanism of action. Cytoplasmically localized anthracyclines appear to also distribute to the mitochondria, which suggests these organelles as possible new anthracycline targets. In contract, doxorubicin shows no mitochondrial localization. These results revealed for the first time that highly lipophilic anthracyclines act as "self-modulators" of MDR. As Lampidis et al. [193] noted, a novel approach to circumventing P-glycoprotein-mediated MDR, and possibly other mechanisms of drug resistance involving nuclear targets, is the use of anthracyclines, which are highly lipophilic and localize in the cytoplasm/mitochondria of cancer cells. However, recently it has been shown that lipophilic anthracyclines in general are transported by P-glycoprotein [195]. Use of drugs that are not transported by P-glycoprotein is an attractive strategy to circumvent MDR. For example, a novel paclitaxel analog, 14-hydroxy-10-deacetylbaccatin III, IDN5109, which is not transported by P-glycoprotein, has shown a 20- to 30-fold higher activity than paclitaxel on MDR cells [196].

\section{CONCLUSIONS}

Significant advances have been made in localizing the drug binding sites of P-glycoprotein for cytotoxic agents and MDR modulators. Since the discovery that P-glycoprotein was labeled with the photoaffinity analogs of vinblastine [18], photoaffinity labeling has evolved as one of the most widely used methods for identifying and characterizing the drug-binding sites of P-glycoprotein. Moreover, investigation of P-glycoprotein mutants, transport studies, and equilibrium binding assays have provided valuable information on drug binding sites of this protein and how they interact with each other. However, the molecular architecture of the drug-binding sites, their exact locations within the P-glycoprotein molecule, and the total number of these sites remain to be determined. Based on P-glycoprotein drug-binding data, it can be concluded that multiple sites interact with the cytotoxic agents and chemosensitizers. Moreover, while evidence suggests that these drug-binding sites are located in TM segments of P-glycoprotein within the lipid bilayer, it is possible that the hydrophobic region(s) of the drugs may bind to the TM segments and the hydrophilic region(s) may interact close to the cytosolic domains of P-glycoprotein near the TM segments [197]. In fact, it has been recently shown that the binding affinities of Pglycoprotein-related drugs increase as the drug-lipid partition coefficient increases [198], suggesting that effective concentrations of the drugs in the membrane are important for interacting with P-glycoprotein. Photoaffinity labeled drugs have been useful for identifying regions of P-glycoprotein that bind to cytotoxic drugs and chemosensitizers. The development of photoaffinity analogs of drugs that contain photoactive groups at different moieties may be useful in determining the spatial arrangement of the drug binding sites. Ultimately, structural resolution in three dimensions will be required to determine the detailed architecture of the drug binding sites. However, the foregoing discussion in this 
review should aid in understanding the complexity of drug binding sites of the drug transporters, and the usefulness of the photoaffinity drugs for identifying MDR-reversing agents.

\section{ACKNOWLEDGMENTS}

I would like to thank Dr. Mary D. Kraeszig for her excellent editorial assistance. The work in the author's laboratory was supported by National Cancer Institute grants CA47652, CA56078 and CA80734, and by American Cancer Society grants DHP-100 and DHP-100A.

\section{REFERENCES}

[1]. Gottesman MM, Fojo T, Bates SE. Nat. Rev. Cancer. 2002; 2:48. [PubMed: 11902585]

[2]. Leonard GD, Polgar O, Bates SE. Curr. Opin. Investig. Drugs. 2002; 3:1652.

[3]. Cole SP, Deely RG. Bioessays. 1998; 20:931. [PubMed: 9872059]

[4]. Kruh GD, Zeng H, Rea PA, Liu G, Chen ZS, Lee K, Belinsky MG. J. Bioenerg. Biomembr. 2001; 33:493. [PubMed: 11804191]

[5]. Wijnholds J. Novartis Found Symp. 2002; 243:69. discussion 80-2,180-5. [PubMed: 11990783]

[6]. Steinbach D, Sell W, Voigt A, Hermann J, Zintle F, Sauerbrey A. Leukemia. 2002; 16:1443. [PubMed: 12145683]

[7]. Faneyte IF, Kristel PM, Maliepaard M, Scheffer GL, Scheper RJ, Schellens JH, van de Vijver MJ. Clin. Cancer Res. 2002; 8:1068. [PubMed: 11948115]

[8]. Gottesman MM, Pastan I, Ambudkar SV. Curr. Opin. Genet. Dev. 1996; 6:610. [PubMed: 8939727]

[9]. Ambudkar SV, Dey S, Hrycyna CA, Ramachandra M, Pastan I, Gottesman MM. Annu. Rev. Pharmacol Toxicol. 1999; 39:361. [PubMed: 10331089]

[10]. Safa, AR. In Principles of Antineoplastic Drug Development and Pharmacology. Schilsky; Ratain; Milano, editors. Marcel Dekker, Inc.; New York: 1996. p. 457-486.

[11]. Greiner B, Eichelbaum M, Fritz P, Kreichgauer HP, von Richter O, Zundler J, Kroemer HK. J. Clin. Invest. 1999; 104:147. [PubMed: 10411543]

[12]. Lee CG, Gottesman MM, Cardarelli CO, Ramachandra M, Jeang KT, Ambudkar SV, Pastan I, Dey S. Biochemistry. 1998; 37:3594. [PubMed: 9530286]

[13]. Ueda K, Okamura N, Hirai M, Tanigawara Y, Saeki T, Kioka N, Komano T, Hori R. J. Biol. Chem. 1992; 267:24248. [PubMed: 1360010]

[14]. Knaust E, Porwit-MacDonald A, Gruber A, Xu D, Peterson C. Leuk. Res. 2003; 27:183. [PubMed: 12526924]

[15]. Charuk JH, Wong PY, Reithmeier RA. Am. J. Physiol. 1995; 269:F31. [PubMed: 7631829]

[16]. Toffoli G, Simone F, Corona G, Raschack M, Cappelietto B, Gigante M, Boiocchi M. Biochem Pharmacol. 1995; 12:1245. [PubMed: 7488241]

[17]. Boulton DW, DeVane CL, Liston HL, Markowitz JS. Life Sci. 2002; 71:163. [PubMed: 12031686]

[18]. Sharma RC, Inoue S, Roitelman J, Schimke RT, Simoni RD. J. Biol. Chem. 1992; 267:5731. [PubMed: 1348245]

[19]. van Helvoort A, Smith AJ, Sprong H, Fritzsche I, Schinkel AH, Borst P, van Meer G. Cell. 1996; 87:507. [PubMed: 8898203]

[20]. Metberall JE, Li H, Waugh K. J. Bio. Chem. 1996; 271:2634. [PubMed: 8576233]

[21]. Ogretmen B, Safa AR. Int. J. Cancer. 1996; 67:608. [PubMed: 8782646]

[22]. Robinson LJ, Roberts WK, Ling TT, Lamming D, Sternberg SS, Roepe PD. Biochemistry. 1997; 136:11169. [PubMed: 9287159]

[23]. Smyth MJ, Krasovskis E, Sutton VR, Johnstone RW. Proc., Natl Acad. Sci. U.S.A. 1998; 95:7024. [PubMed: 9618532] 
[24]. Bezombes C, Maestre N, Laurent G, Levade T, Bettaieb A, Jaffrezou JP. FASEB J. 1998; 12:101. [PubMed: 9438415]

[25]. Johnstone RW, Cretney E, Smyth MJ. Blood. 1999; 93:1075. [PubMed: 9920858]

[26]. Johnstone RW, Ruefli AA, Smyth MJ. Trends Biochem. Sci. 2000; 25:1. [PubMed: 10637601]

[27]. Pallis M, Russell N. Blood. 2000; 95:2897. [PubMed: 10779437]

[28]. Ruefli AA, Tainton KM, Darcy PK, Smyth MJ, Johnstone RW. Cell Death Differ. 2002; 9:1266. [PubMed: 12404126]

[29]. Chan HS, Thorner PS, Haddad G, Ling V. J. Clin. Oncol. 1990; 8:689. [PubMed: 1968964]

[30]. Baldini N, Scotlandi K, Barbanti-Brodano G, Manara MC, Maurici D, Bacci G, Bertoni F, Picci P, Sottili S, Campanacci M, Serra M. N. Engl. J. Med. 1995; 333:1380. [PubMed: 7477118]

[31]. Gregorcyk S, Kang Y, Brandt D, Kolm P, Singer G, Perry RR. Ann. Surg. Oncol. 1996; 3:8. [PubMed: 8770296]

[32]. Abolhoda A, Wilson AE, Ross H, Danenberg PV, Burt M, Scotto KW. Clin. Cancer. Res. 1999; 5:3352. [PubMed: 10589744]

[33]. Yokoyama Y, Sato S, Fukushi Y, Sakamoto T, Futagami M, Saito Y. J. Obstet. Gynaecol. Res. 1999; 25:387. [PubMed: 10680335]

[34]. Nooter K, Sonneveld P. Leuk. Res. 1994; 18:233. [PubMed: 7909572]

[35]. Zochbauer S, Gsur A, Brunner R, Kyrie PA, Lechner K, Pirker R. Leukemia. 1994; 8:974. [PubMed: 7516030]

[36]. Zhou DC, Zittoun R, Marie JP. Leukemia. 1995; 9:1661. [PubMed: 7564506]

[37]. Willman CL. Semin. Hematol. 1997; 34(4 Suppl 5):25. [PubMed: 9408958]

[38]. Del Poeta G, Venditti A, Stasi R, Aronica G, Cox MC, Buccisano F, Tamburini A, Bruno A, Maurillo L, Battaglia A, Suppo G, Epiceno AM, Del Moro B, Masi M, Amadori S, Papa G. Leuk. Res. 1999; 23:451. [PubMed: 10374859]

[39]. Musto P, Melillo L, Lombardi G, Matera R, di Giorgio G, Carotenuto M. Br. J. Haematol. 1991; 77:50. [PubMed: 1671821]

[40]. Gottesman MM, Pastan I. Annu. Rev. Biochem. 1993; 62:385. [PubMed: 8102521]

[41]. Roninson, IB.; Pastan, I.; Gottesman, MM. In Molecular and Cellular Biology of Multidrug Resistance in Tumor Cells. Roninson, editor. Plenum Press; New York and London: 1991. p. 91-104.

[42]. Sharom FJ. J. Membr. Biol. 1997; 160:161. [PubMed: 9425600]

[43]. Higgins CF, Callaghan R, Linton KJ, Rosenberg MF, Ford RC. Semin. Cancer Biol. 1997; 8:135. [PubMed: 9441943]

[44]. Jones PM, George AM. J. Membr. Biol. 1998; 166:133. [PubMed: 9841738]

[45]. Jones PM, George AM. Eur. J. Biochem. 2000; 267:5298. [PubMed: 10951188]

[46]. Cornwell MM, Tsuruo T, Gottesman MM, Pastan I. FASEB J. 1997; 1:51. [PubMed: 2886389]

[47]. Hamada H, Tsuruo T. J. Biol. Chem. 1988; 263:1454. [PubMed: 2891711]

[48]. al-Shawi MK, Urbatsch IL, Senior AE. J. Biol. Chem. 1994; 269:8986. [PubMed: 7907596]

[49]. Senior AE, at-Shawi MK, Urbatsch IL. FEBS Lett. 1995; 377:285. [PubMed: 8549739]

[50]. Urbatsch IL, Sankaran B, Bhagat S, Senior AE. J. Biol. Chem. 1995; 270:26956. [PubMed: 7592942]

[51]. Sauna ZE, Ambudkar SV. Proc. Natl. Acad. Sci. U.S.A. 2000; 97:2515. [PubMed: 10716986]

[52]. Loo TW, Clarke DM. Proc. Natl. Acad. Sci. U.S.A. 2002; 99:3511. [PubMed: 11891276]

[53]. Loo TW, Bartlett MC, Clarke DM. J. Biol. Chem. 2003; 278:1575. [PubMed: 12421806]

[54]. Ruth A, Stein WD, Rose E, Roninson IB. Biochemistry. 2001; 40:4332. [PubMed: 11284689]

[55]. Druley TE, Stein WD, Ruth A, Roninson LB. Biochemistry. 2001; 40:4323. [PubMed: 11284688]

[56]. Liu R, Siemiarczuk A, Sharom FJ. Biochemistry. 2000; 39:14927. [PubMed: 11101309]

[57]. Wang G, Pincheira R, Zhang M, Zhang JT. Biochem., J. 1997; 328:897. [PubMed: 9396736]

[58]. Sonveaux N, Shapiro AB, Goormaghtigh E, Ling V, Ruysschaert JM. J. Biol. Chem. 1996; 271:24617. [PubMed: 8798727] 
[59]. Sonveaux N, Vigano C, Shapiro AB, Ling V, Ruysschaert JM. J. Biol. Chem. 1999; 274:17649. [PubMed: 10364203]

[60]. Ambudkar SV, Lelong IH, Zhang J, Cardarelli CO, Gottesman MM, Pastan I. Proc. Natl. Acad. Sci., U.S.A. 1992; 89:8472. [PubMed: 1356264]

[61]. Sarkadi B, Price EM, Boucher RC, Germann UA, Scarborough GA. J. Biol. Chem. 1992; 267:4854. [PubMed: 1347044]

[62]. Hrycyna CA, Ramachandra M, Ambudkar SV, Ko YH, Pedersen PL, Pastan I, Gottesman MM. J. Biol. Chem. 1998; 273:16631. [PubMed: 9642211]

[63]. Loo TW, Clarke DM. J. Biol Chem. 2000; 275:19435. [PubMed: 10806188]

[64]. Sauna ZE, Smith MM, Muller M, Ambudkar SV. J. Biol. Chem. 2001; 276:33301. [PubMed: 11451943]

[65]. Buxbaum E. Eur. J. Biochem. 1999; 265:54. [PubMed: 10491157]

[66]. Buxbaum E. Eur. J. Biochem. 1999; 265:64. [PubMed: 10491158]

[67]. Varadi A, Szakacs G, Bakos E, Sarkadi B. Novartis. Found. Symp. 2002; 243:54-65. discussion 65-8. [PubMed: 11990782]

[68]. Qu Q, Russell PL, Sharom FJ. Biochemistry. 2003; 42:1170. [PubMed: 12549939]

[69]. Rosenberg MF, Callaghan R, Ford RC, Higgins CF. J. Biol Chem. 1997; 272:10685. [PubMed: 9099718]

[70]. Rosenberg MF, Kamis AB, Callaghan R, Higgins CF, Ford RC. J. Biol. Chem. 2003; 278:8294. [PubMed: 12501241]

[71]. Szabo D, Keyzer H, Kaiser HE, Molnar J. Anticancer Res. 2000; 20:261.

[72]. Tan B, Piwnica-Worms D, Ratner L. Curr. Opin. Oncol. 2000; 12:450. [PubMed: 10975553]

[73]. Bates SF, Chen C, Robey R, Kang M, Figg WD, Fojo T. Novartis. Found. Symp. 2002; 243:8396. discussion 96-102. [PubMed: 11990784]

[74]. Stein WD. Curr. Opin. Investig. Drugs. 2002; 3:812.

[75]. Safa AR. Methods Enzymol. 1998; 292:289. [PubMed: 9711562]

[76]. Safa AR, Glover CJ, Meyers MB, Biedler JL, Felsted RL. J. Biol. Chem. 1986; 207:6137. [PubMed: 3700389]

[77]. Beck WT, Cirtain MC, Glover CJ, Felsted RL, Safa AR. Biochem. Biophys. Res. Commun. 1988; 153:959. [PubMed: 2898941]

[78]. Safa AR, Stern RK, Choi K, Agresti M, Tamai I, Mehta ND, Roninson IB. Proc. Natl. Acad. Sci. U.S.A. 1990; 87:7225. [PubMed: 1976255]

[79]. Cornwell MM, Safa AR, Felsted RL, Gottesman MM, Pastan I. Proc Natl Acad Sci U.S.A. 1986; 83:3847. [PubMed: 3459160]

[80]. Safa AR. Drug Resist Updat. 1999; 2:371. [PubMed: 11498353]

[81]. Busche R, Tummler B, Riordan JR, Cano-Gauci DF. Mol. Pharmacol. 1989; 35:414. [PubMed: 2565017]

[82]. Beck WT, Qian XD. Biochem. Pharmacol. 1992; 43:89. [PubMed: 1346496]

[83]. Safa AR, Mehta ND, Agresti M. Biochem. Biophys. Res. Commun. 1989; 162:1402. [PubMed: 2569869]

[84]. Nare B, Lui Z, Prichard RK, Georges E. Biochem. Pharmacol. 1994; 48:2215. [PubMed: 7811303]

[85]. Nare B, Prichard RK, Georges E. Mol. Pharmacol. 1994; 45:1145. [PubMed: 7912815]

[86]. Ojima I, Bounaud PY, Ahern DG. Bioorg. Med. Chem. Lett. 1999; 9:1189. [PubMed: 10328311]

[87]. Wu Q, Bounaud PY, Kuduk SD, Yang CP, Ojima I, Horwitz SB, Orr GA. Biochemistry. 1998; 37:11272. [PubMed: 9698374]

[88]. Andrus MB, Turner TM, Sauna ZE, Ambudkar SV. Bioorg. Med. Chem. Lett. 2000; 10:2275. [PubMed: 11055337]

[89]. Safa AR, Glover CJ, Sewell JL, Meyers MB, Biedler JL, Felsted RL. J. Biol. Chem. 1987; 262:7884. [PubMed: 3034908]

[90]. Safa AR. Proc. Natl. Acad. Sci., U.S.A. 1998; 85:7187. [PubMed: 2902625]

[91]. Qian XD, Beck WT. Cancer Res. 1990; 50:1132. [PubMed: 1967551] 
[92]. Borchers C, Ulrich WR, Klemm K, Ise W, Gekeler V, Haas S, Schodl A, Conrad J, Przybylski M, Boer R. Mol. Pharmacol. 1995; 48:21. [PubMed: 7623771]

[93]. Safa AR, Agresti M, Tamai I, Mehta ND, Vahabi S. Biochem. Biophys. Res. Commun. 1990; 166:259. [PubMed: 1967938]

[94]. Safa AR, Agresti M, Bryk D, Tamai I. Biochemistry. 1994; 33:256. [PubMed: 7904476]

[95]. Akiyama S, Yoshimura A, Kikuchi H, Sumizawa T, Kuwano M, Tahara Y. Mol. Pharmacol. 1989; 36:730. [PubMed: 2573823]

[96]. Foxwell BM, Mackie A, Ling V, Ryffel B. Mol Pharmacol. 1989; 36:543. [PubMed: 2572960]

[97]. Morris DI, Speicher LA, Ruoho AE, Tew KD, Seamon KB. Biochemistry. 1991; 30:8371. [PubMed: 1679346]

[98]. Speicher LA, Barone LR, Chapman AE, Hudes GR, Laing N, Smith CD, Tew KD. J. Natl. Cancer Inst. 1994; 86:688. [PubMed: 7908988]

[99]. Qian XD, Beck WT. J. Biol. Chem. 1990; 265:18753. [PubMed: 1977745]

[100]. Wolf DC, Horwitz SB. Int. J. Cancer. 1992; 52:141. [PubMed: 1354202]

[101]. Germann UA, Ford PJ, Shlyakhter D, Mason VS, Harding MW. Anticancer Drugs. 1997; 8:141. [PubMed: 9073310]

[102]. Germann UA, Shlyakhter D, Mason VS, Zelle RE, Duffy JP, Galullo V, Armistead DM, Saunders JO, Boger J, Harding MW. Anticancer Drugs. 1997; 8:125. [PubMed: 9073309]

[103]. Yanagisawa T, Newman A, Coley H, Renshaw J, Pinkerton CR, Pritchard-Jones K. Br. J. Cancer. 1999; 80:1190. [PubMed: 10376971]

[104]. Bruggemann EP, Currier SJ, Gottesman MM, Pastan I. Characterization of the azidopine and vinblastine binding site of P-glycoprotein. J. Biol. Chem. 1992; 267:21020. [PubMed: 1356986]

[105]. Greenberger LM. J. Biol. Chem. 1993; 268:11417. [PubMed: 8098711]

[106]. Morris DI, Greenberger LM, Bruggemann EP, Cardarelli C, Gottesman MM, Pastan I, Seamon KB. Mol. Pharmacol. 1994; 46:329. [PubMed: 7915819]

[107]. Demmer A, Thole H, Kubesch P, Brandt T, Raida M, Fislage R, Tummler B. J. Biol. Chem. 1997; 272:20913. [PubMed: 9252419]

[108]. Wang EJ, Casciano CN, Clement RP, Johnson WW. Biochem. Biophys. Res. Commun. 2001; 289:580. [PubMed: 11716514]

[109]. Tamai I, Safa AR. J. Biol. Chem. 1990; 265:16509. [PubMed: 1975813]

[110]. Safa, AR. In Multidrug Resistance in Cancer Cells. Gupta; Tsuruo, editors. Sons, Ltd.; New York: John Wiley: 1996. p. 231-250.

[111]. Sonveaux N, Vigano C, Shapiro AB, Ling V, Ruysschaert JM. J. Biol. Chem. 1999; 274:17649. [PubMed: 10364203]

[112]. Borchers C, Boer R, Klemm K, Figala V, Denzinger T, Ulrich WR, Haas S, Ise W, Gekeler V, Przybylski M. Mol. Pharmacol. 2002; 61:1366. [PubMed: 12021398]

[113]. Ayesh S, Shao YM, Stein WD. Biochim. Biophys. Acta. 1996; 1316:8. [PubMed: 8634345]

[114]. Martin C, Berridge G, Higgins CF, Callaghan R. Br. J. Pharmacol. 1997; 122:765. [PubMed: 9375975]

[115]. Pascaud C, Garrigos M, Orlowski S. Biochem. J. 1998; 333:351. [PubMed: 9657975]

[116]. Tamai I, Safa AR. J. Biol. Chem. 1991; 266:16796. [PubMed: 1679434]

[117]. Ferry DR, Russell MA, Cullen MH. Biochem. Biophys. Res. Commun. 1992; 188:440. [PubMed: 1358068]

[118]. Martin C, Berridge G, Higgins C,F, Mistry P, Charlton P, Callaghan R. Mol. Pharmacol. 2000; 58:624. [PubMed: 10953057]

[119]. Shao YM, Ayesh S, Stein WD. Biochim. Biophys. Acta. 1997; 1360:30. [PubMed: 9061037]

[120]. Boer R, Dichtl M, Borchers C, Ulrich WR, Marecek JF, Prestwich GD, Gtossmann H, Striessnig J. Biochemistry. 1996; 35:1387. [PubMed: 8634268]

[121]. Garrigos M, Mir LM, Orlowski S. Eur. J. Biochem. 1997; 244:662.

[122]. Fleming GF, Amato JM, Agresti M, Safa AR. Cancer Chemother. Pharmacol. 1992; 29:445. [PubMed: 1348973]

[123]. Shapiro AB, Fox K, Lam P, Ling V. Eur. J. Biochem. 1999; 259:841. [PubMed: 10092872] 
[124]. Borgnia MJ, Eylan GD, Assaraf YG. J Biol. Chem. 1996; 271:3163. [PubMed: 8621716]

[125]. Martin C, Higgins CF, Callaghan R. Biochemistry. 2001; 40:15733. [PubMed: 11747450]

[126]. Stein WD. Exp. Physiol. 1998; 83:221. [PubMed: 9568482]

[127]. Loo TW, Clarke DM. J. Biol. Chem. 2000; 275:39272. [PubMed: 11013259]

[128]. Loo TW, Clarke DM. J. Biol. Chem. 2001; 276:14972. [PubMed: 11279063]

[129]. Loo TW, Clarke DM. J. Biol. Chem. 2002; 277:44332. [PubMed: 12223492]

[130]. Choi KH, Chen CJ, Kriegler M, Roninson IB. Cell. 1988; 53:519. [PubMed: 2897240]

[131]. Chen GK, Lacayo NJ, Duran GE, Cohen D, Sikic BI. Mol. Pharmacol. 2000; 57:769. [PubMed: 10727524]

[132]. Devine SE, Ling V, Melera PW. Proc. Natl. Acad Sci., U.S.A. 1992; 89:4564. [PubMed: 1350094]

[133]. Taguchi Y, Kino K, Morishima M, Komano T, Kane SE, Ueda K. Biochemistry. 1997; 36:8883. [PubMed: 9220975]

[134]. Currier SJ, Kane SE, Willingham MC, Cardarelli CO, Pastan I, Gottesman MM. J. Biol. Chem. 1992; 267:25153. [PubMed: 1360983]

[135]. Kajiji S, Talbot F, Grizzuti K, Van Dyke-Phillips V, Agresti M, Safa AR, Gros P. Biochemistry. 1993; 32:4185. [PubMed: 7682843]

[136]. Hafkemeyer P, Dey S, Ambudkar SV, Hrycyna CA, Pastan I, Gottesman MM. Biochemistry. 1998; 37:16400. [PubMed: 9819232]

[137]. Dey S, Hafkemeyer P, Pastan I, Gottesman MM. Biochemistry. 1999; 38:6630. [PubMed: 10350482]

[138]. Loo TW, Clarke DM. Biochem. Cell Biol. 1999; 77:11. [PubMed: 10426282]

[139]. Zhang X, Collins KI, Greenberger LM. J. Biol. Chem. 1995; 270:5441. [PubMed: 7890659]

[140]. Loo TW, Clarke DM. J. Biol Chem. 2000; 275:5253. [PubMed: 10681495]

[141]. Loo TW, Clarke DM. J. Biol. Chem. 1997; 272:20986. [PubMed: 9261097]

[142]. Chen G, Duran GE, Steger KA, Lacayo NJ, Jaffrezou JP, Dumontet C, Sikic BI. J. Biol. Chem. 1997; 272:5974. [PubMed: 9038218]

[143]. Song J, Melera PW. Mol. Pharmacol. 2001; 60:254. [PubMed: 11455011]

[144]. Gruol DJ, King MN, Kuehne ME. Mol. Pharmacol. 2002; 62:1238. [PubMed: 12391288]

[145]. Gruol DJ, Bernd J, Phippard AE, Ojima I, Bernacki RJ. Mol. Pharmacol. 2001; 60:104. [PubMed: 11408605]

[146]. Skovsgaard T. Cancer Res. 1980; 40:1077. [PubMed: 7357538]

[147]. Tsuruo T, Iida H, Tsukagoshi S, Sakurai Y. Cancer Res. 1981; 41:1967. [PubMed: 7214365]

[148]. Ford JM, Hait WN. Pharmacol. Rev. 1990; 42:155. [PubMed: 2217530]

[149]. Beck, WT. In Molecular and Clinical Advances in Anticancer Drug Resistance. Ozols, RF., editor. Kluwer Academic Publishers; Boston: 1991. p. 151-169.

[150]. Tew, KD.; Houghton, PJ.; Houghton, JA. In Preclnical and Clinical Modulation of Anticancer Drugs. Tew, KD.; Houghton, PJ.; Houghton, JA., editors. CRC Press; Boca Raton, FL: 1993. p. 125-196.

[151]. Sikic BI, Fisher GA, Lum BL, Halsey J, Beketic-Oreskovic L, Chen G. Cancer Chemother. Pharmacol. 1997; (40 Suppl):S13.

[152]. Tan B, Piwnica-Worms D, Ratner L. Curr. Opin. Oncol. 2000; 12:450. [PubMed: 10975553]

[153]. Stein WD. Exp. Physiol. 1998; 83:221. [PubMed: 9568482]

[154]. Pearce HL, Safa AR, Bach NJ, Winter MA, Cirtain MC, Beck WT. Proc. Natl Acad. Sci. U.S.A. 1989; 86:5128. [PubMed: 2567994]

[155]. Pearce HL, Winter MA, Beck WT. Adv. Enzyme. Regul. 1990; 30:357. [PubMed: 1976291]

[156]. Borgnia MJ, Eytan GD, Assaraf YG. J. Biol. Chem. 1996; 271:3163. [PubMed: 8621716]

[157]. Seelig A. Int. J. Clin. Pharmacol. Ther. 1998; 36:50. [PubMed: 9476149]

[158]. Seelig A. Eur. J. Biochem. 1998; 251:252. [PubMed: 9492291]

[159]. Seelig A, Landwojtowicz E. Eur. J. Pharm. Sci. 2000; 12:31. [PubMed: 11121731]

Curr Med Chem Anticancer Agents. Author manuscript; available in PMC 2015 May 28. 
[160]. Lovekamp T, Cooper PS, Hardison J, Bryant SD, Guerrini R, Balboni G, Salvadori S, Lazarus LH. Brain. Res. 2001; 902:131. [PubMed: 11376603]

[161]. Pajeva IK, Wiese M. J. Med. Chem. 2002; 45:5671. [PubMed: 12477351]

[162]. Ecker GF, Csaszar E, Kopp S, Plagens B, Holzer W, Ernst W, Chiba P. Mol. Pharmacol. 2002; 61:637. [PubMed: 11854445]

[163]. Penzolti JE, Lamb ML, Evensen E, Grootenhuis PD. J. Med. Chem. 2002; 45:1737. [PubMed: 11960484]

[164]. Ekins S, Kim RB, Leake BF, Dantzig AH, Schuetz EG, Lan LB, Yasuda K, Shepard RL, Winter MA, Schuetz JD, Wikel JH, Wrighton SA. Mol. Pharmacol. 2002; 61:974. [PubMed: 11961114]

[165]. Ekins S, Kim RB, Leake BF, Dantzig AH, Schuetz EG, Lan LB, Yasuda K, Shepard RL, Winter MA, Schuetz JD, Wikel JH, Wrighton SA. Mol Pharmacol. 2002; 61:964. [PubMed: 11961113]

[166]. Garrigues A, Loiseau N, Delaforge M, Ferte J, Garrigos M, Andre F, Orlowski S. Mol. Pharmacol. 2002; 62:1288. [PubMed: 12435795]

[167]. Ueda K, Okamura N, Hirai M, Tanigawara Y, Saeki T, Kioka N, Komano T, Hori R. J. Biol. Chem. 1992; 267:24248. [PubMed: 1360010]

[168]. Dantzig AH, Shepard RL, Cao J, Law KL, Ehlhardt WJ, Baughman TM, Bumol TF, Starling JJ. Cancer Res. 1996; 56:4171. [PubMed: 8797588]

[169]. Mistry P, Stewart AJ, Dangerfield W, Okiji S, Liddle C, Bootle D, Plumb JA, Templeton D, Charlton P. Cancer Res. 2001; 61:749. [PubMed: 11212278]

[170]. Saeki T, Ueda K, Tanigawara Y, Hori R, Komano T. J. Biol. Chem. 1993; 268:6077. [PubMed: 7681059]

[171]. Pouliot JF, L'Heureux F, Liu Z, Prichard RK, Georges E. Biochem. Pharmacol. 1997; 53:17. [PubMed: 8960059]

[172]. Samuels BL, Mick R, Vogelzang NJ, Williams SF, Schilsky RL, Safa AR, O'Brien SM, Ratain M. J. Clin. Pharmacol., Ther. 1993; 54:421.

[173]. Lum BL, Fisher GA, Brophy NA, Yahanda AM, Adler KM, Kaubisch S, Halsey J, Sikic BI. Cancer. 1993; 72(11 Suppl):3502. [PubMed: 7902206]

[174]. Ferry DR, Traunecker H, Kerr DJ. Eur. J. Cancer. 1996; 32A:1070. [PubMed: 8763349]

[175]. Sikic BI. Semin. Hematol. 1997; 34(4 Suppl 5):40. [PubMed: 9408960]

[176]. Boesch D, Gaveriaux C, Jachez B, Pourtier-Manzanedo A, Bollinger P, Loor F. Cancer Res. 1991; 51:4226. [PubMed: 1678313]

[177]. Hyafil F, Vergely C, Du Vignaud P, Grand-Perrct T. Cancer Res. 1993; 53:4595. [PubMed: 8402633]

[178]. Mistry P, Plumb J, Ecclcs S, Watson S, Dale I, Ryder H, Box G, Charlton P, Templeton D, Bevan PB. Br. J. Cancer. 1999; 79:1672. [PubMed: 10206276]

[179]. Fields A, Hochster H, Runowicz C, Speyer J, Goldberg G, Cohen C, Dottino P, Wadler S, Berk G, Gretz H, Mandeli J, Holland J, Letvak L. Curr. Opin. Oncol. 1998; 10(Supp 11):S21. [PubMed: 9988540]

[180]. Advani R, Saba HI, Tallman MS, Rowe JM, Wiernik PH, Ramek J, Dugan K, Lum B, Villena J, Davis E, Paielta E, Litchman M, Sikic BI, Greenberg PL. Blood. 1999; 93:787. [PubMed: 9920827]

[181]. Rowinsky E,K, Smith L, Wang YM, Chaturvedi P, Villalona M, Campbell E, Aylesworth C, Eckhardt SG, Hammond L, Kraynak M, Drengler R, Stephenson J Jr. Harding MW, Von Hoff DD. J. Clin. Oncol. 1998; 16:2964. [PubMed: 9738565]

[182]. Fisher GA, Lum BL, Hausdorff J, Sikic BI. Ear. J. Cancer. 1996; 32A:1082.

[183]. Advani R, Fisher GA, Lum BL, Hausdorff J, Halsey J, Litchman M, Sikic BI. Clin. Cancer Res. 2001; 7:1221. [PubMed: 11350887]

[184]. Roe M, Folkes A, Ashworth P, Brumwell J, Chima L, Hunjan S, Pretswcll I, Dangerfield W, Ryder H, Charlton P. Bioorg. Med. Chem. Lett. 1999; 9:595. [PubMed: 10098671]

[185]. Martin C, Berridge G, Mistry P, Higgins C, Charlton P, Callaghan R. Br. J. Pharmacol. 1999; 128:403. [PubMed: 10510451] 
[186]. Rubin EH, de Alwis DP, Pouliquen I, Green L, Marder P, Lin Y, Musanti R, Grospe SL, Smith SL, Toppmeyer DL, Much J, Kane M, Chaudhary A, Jordan C, Burgess M, Slapak CA. Clin. Cancer Res. 2002; 8:3710. [PubMed: 12473580]

[187]. Dantzig AH, Law KL, Cao J, Starling J. J. Curr. Med. Chem. 2001; 8:39.

[188]. Rao VV, Chiu ML, Kronauge JF, Piwnica-Worms D. J. NucL. Med. 1994; 35:510. [PubMed: 7906729]

[189]. Piwnica-Worms D, Chiu ML, Budding M, Kronauge JF, Kramer RA, Croop JM. Cancer Res. 1993; 53:977. [PubMed: 8094997]

[190]. Slapak CA, Dahlheimer J, Piwnica-Worms D. J. Clin. Pharmacol. 2001; (Suppl):29S. [PubMed: 11452726]

[191]. Kim R, Osaki A, Hirai T, Toge T. Breast Cancer. 2002; 9:240. [PubMed: 12185336]

[192]. Agrawal M, Abraham J, Balis FM, Edgerly M, Stein WD, Bates S, Fojo T, Chen CC. Clin. Cancer Res. 2003; 9:650. [PubMed: 12576431]

[193]. Lampidis TJ, Kolonias D, Podona T, Israel M, Safa AR, Lothstein L, Savaraj N, Tapiero H, Priebe W. Biochemistry. 1997; 36:2679. [PubMed: 9054575]

[194]. Safa AR. Cancer Invest. 1993; 11:46. [PubMed: 8093677]

[195]. Marbeuf-Gueye C, Broxterman HJ, Dubru F, Priebe W, Gamier-Suillerot A. Mol. Pharmacol. 1998; 53:141. [PubMed: 9443942]

[196]. Polizzi D, Pratesi G, Tortoreto M, Supino R, Riva A, Bombardelli E, Zunino F. Cancer Res. 1999; 59:1036. [PubMed: 10070960]

[197]. Hait WN, Aftab DT. Biochem. Pharmacol. 1992; 43:103. [PubMed: 1346493]

[198]. Romsicki Y, Sharom FJ. Biochemistry. 1999; 38:6887. [PubMed: 10346910] 
(1)

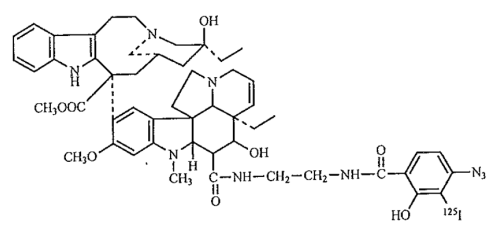

(2)

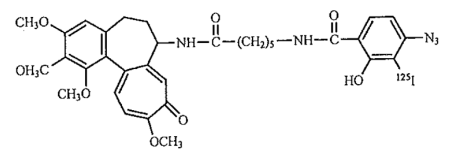

(3)

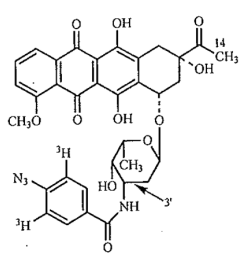

(4)

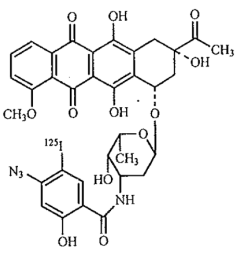

(5)

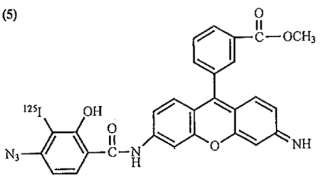

(ต)

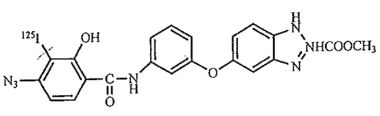

(7)

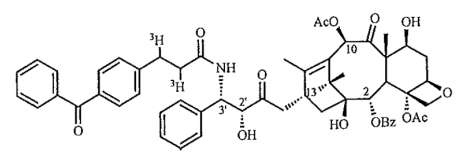

Fig. (1).

Structures of photoaffinity analogs of MDR-related drugs known to covalently label Pglycoprotein: (I) [ $\left.{ }^{125} \mathrm{I}\right] \mathrm{NASV}$, (2) [ $\left.{ }^{125} \mathrm{I}\right] \mathrm{NASC}$, (3) $\left[{ }^{3} \mathrm{H}\right] \mathrm{NAB}-\mathrm{DNR}$, (4) $\left[{ }^{125} \mathrm{I}\right] \mathrm{NAS}-\mathrm{DNR},(5)$ $\left[{ }^{125} \mathrm{I}\right] \mathrm{ASA}-\mathrm{Rh} 123,(6)$ [ $\left.{ }^{125} \mathrm{I}\right] \mathrm{ASA}-\mathrm{BZ}$, and (7) $\left[{ }^{3} \mathrm{H}\right] \mathrm{BzDC}-$ paclitaxel. 


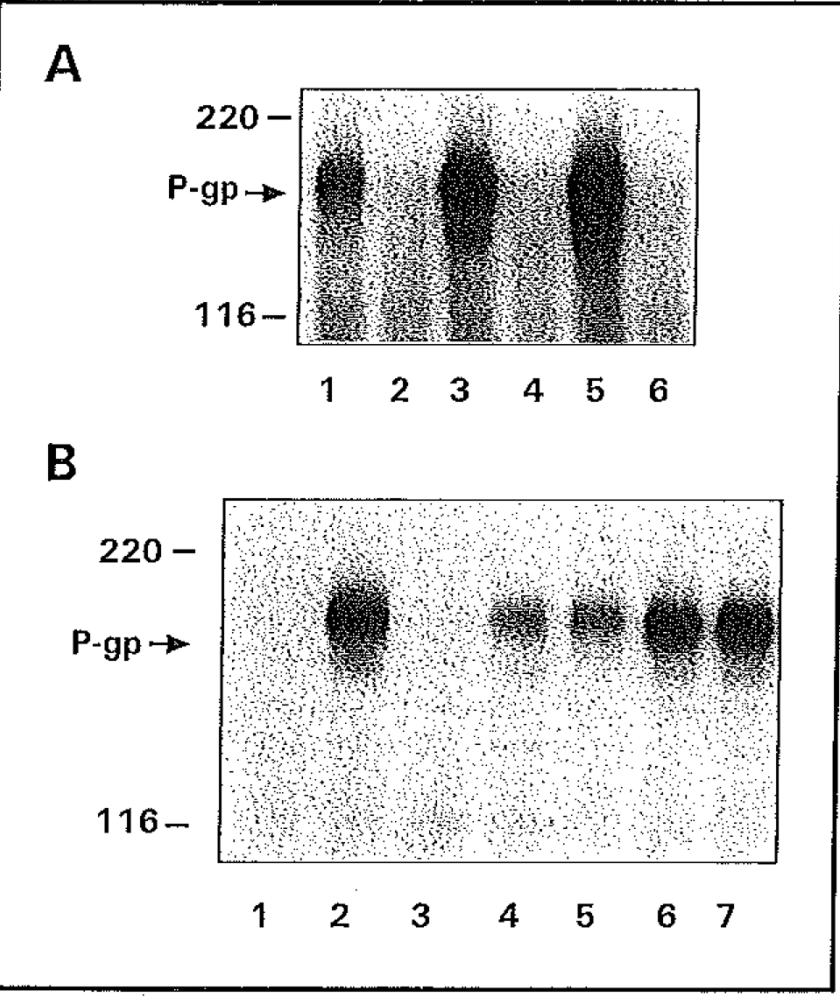

Fig. (2).

(A) Autoradiogram of $\left[{ }^{125} \mathrm{I}\right] \mathrm{NASV}$ photolabeled plasma membranes (20 $\mu \mathrm{g}$ protein) from CEM, CEM/VBL100, CEM/VBL1000 and CEM/VBL5000 cells in the absence (lanes 1, 2, 4 and 6) or presence of $10 \mu \mathrm{M}$ nonradioactive vinblastine (lanes 3, 5 and 7). (B) Autoradiogram of [ $\left.{ }^{125} \mathrm{I}\right] \mathrm{NASV}$ photoaffinity labeled KB-3-1 (lane 1) and KB-GRC1 transfectants (KB-3-1 cells transfected with the MDR1 gene) (lanes 2-7), KB-GRC1 transfectants $\left(8 \times 10^{6}\right.$ cells $)$ were photoaffinity labeled with $50 \mathrm{nM}\left[{ }^{125} \mathrm{I}\right] \mathrm{NASV}(50-60 \mathrm{Ci} /$ mMole) in the absence (lane 2) or presence of $100 \mu \mathrm{M}$ vinblastine, actinomycin $\mathrm{D}$, doxorubicin, colchicine, or methotrexate, respectively (lanes 3-7), and after subjecting to SDS-PAGE, the samples were processed for autoradiography. 

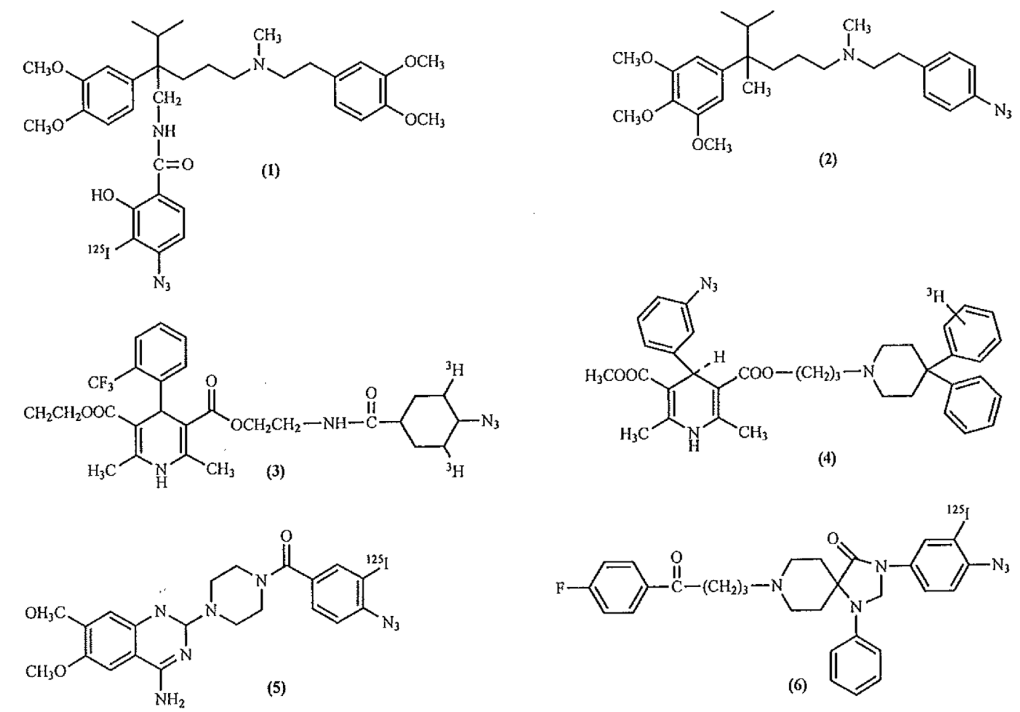

Fig. (3).

Structures of photoaffinity analogs of MDR modulators known to covalently label Pglycoprotein: (1) [ $\left.{ }^{125} \mathrm{I}\right] \mathrm{NAS}-\mathrm{VP},(2) \mathrm{LU}-49888$, (3) [ $\left.{ }^{3} \mathrm{H}\right]$ azidopme, (4) $\left[{ }^{3} \mathrm{H}\right] \mathrm{B} 92009-005$, (5) $\left[{ }^{125} \mathrm{I}\right] \mathrm{AAP}$ and $(6)\left[{ }^{125} \mathrm{I}\right] \mathrm{NAPS}$. 


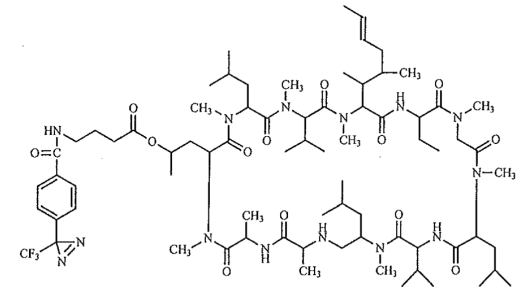

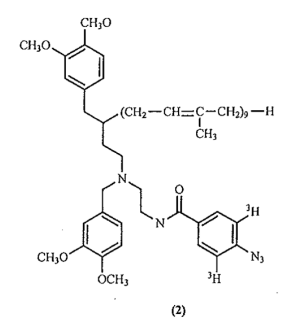

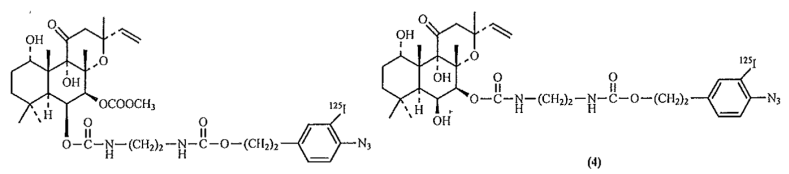

(3)

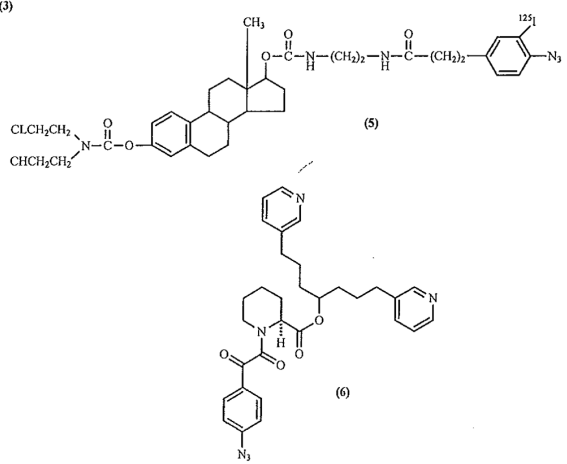

Fig. (4).

Structures of photoaffinity analogs of MDR modulators known to covalently label Pglycoprotein: (1) cyclosporin aziridine, (2) synthetic isoprenoid, (3) $N$-solanesyl- $N^{\prime}, N^{\prime}$-bis(3, 4-dimethoxybenzoyl)ethylenediamine, (4) forskolin analogs, (5) estramustine photoaffinity analog, and (6) VF-13.

Curr Med Chem Anticancer Agents. Author manuscript; available in PMC 2015 May 28. 


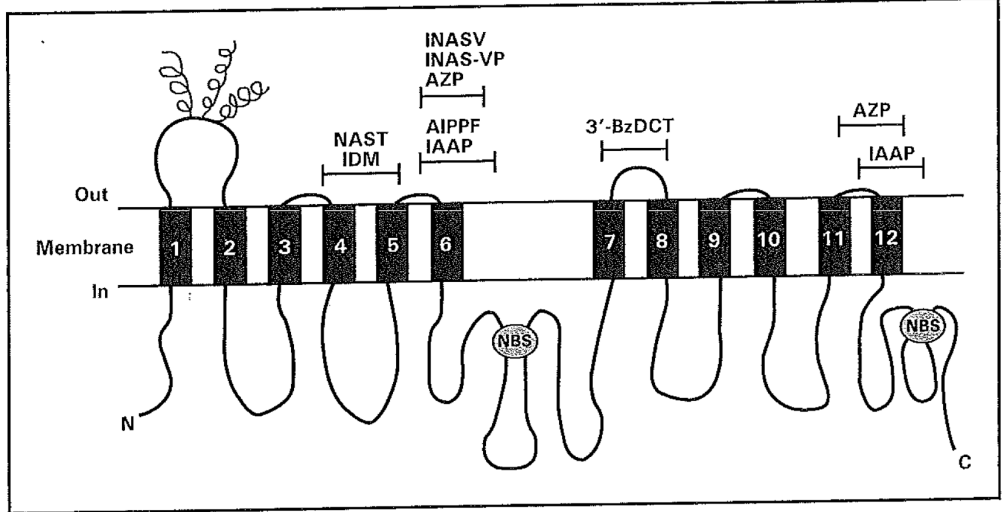

Fig. (5).

Topological model of P-glycoprotein and the approximate locations of its drug binding sites. The figure shows the structure of P-glycoprotein with twelve transmembrane domains (TMDs) predicted by hydrophobicity plot. Domains of the protein that are involved in the binding of iodomycin (IDM), [ $\left.{ }^{125} \mathrm{I}\right] \mathrm{NASV},\left[{ }^{125} \mathrm{I}\right] \mathrm{NAS}-\mathrm{VP},\left[{ }^{125} \mathrm{I}\right] \mathrm{NAST},\left[{ }^{3} \mathrm{H}\right]$ azidopine (AZP), 6-o-[[2-[3-(4-azido-3-[ ${ }^{125}$ I]iodophenyl) propionamido]ethyl]-carbamyl)forskolin (AIPPF), $\left[{ }^{125} \mathrm{I}\right]$ iodoarylazidoprazosin (IAAP), $\left[{ }^{3} \mathrm{H}\right]-3$-BzDC-paclitaxel, $\left[{ }^{3} \mathrm{H}\right]-7-B z D C-$ paclitaxel (dashed lines, amino acid residues 985-1008 are marked). For details, see the text. 


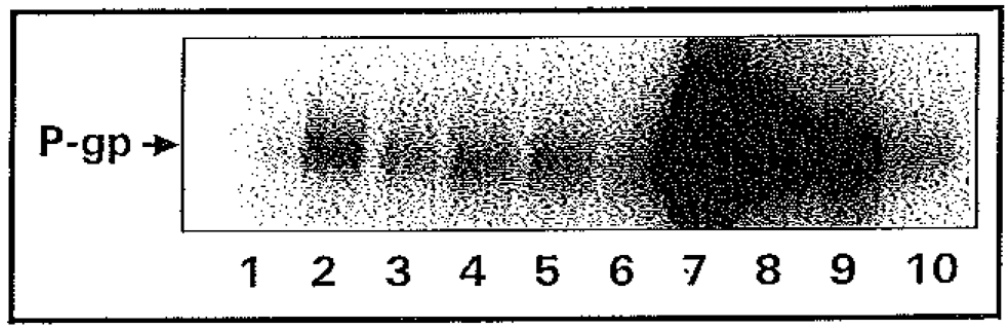

Fig. (6).

Photoaffinity labeling of P-glycoprotein from SH-SY5Y/VCR cells with [ $\left.{ }^{125} \mathrm{I}\right] \mathrm{AAP}$ (lane 1) and the effects of $100 \mu \mathrm{M}$ trifluoperazine, chlorpromazine, thioridazine, perphenazine, $\mathrm{W}-7$, cis-flupentixol, trans-flupentixol, fluphenazine and fluphenazine N-mustard (lanes 2-10), respectively. 


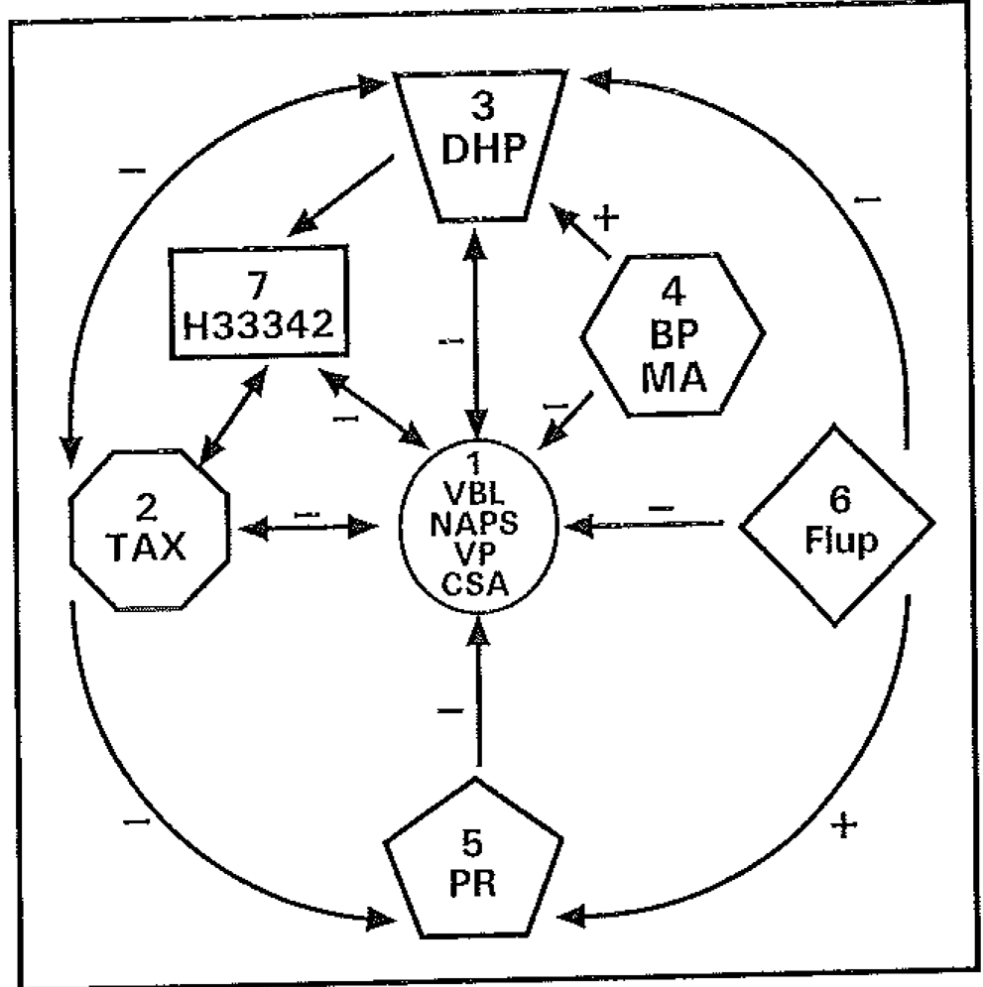

Fig. (7).

Proposed classification of multiple drug binding sites of P-glycoprotein. Based on the kinetic analysis of drug binding to P-glycoprotein under equilibrium conditions and photoaffinity labeling using various photoaffinity analogs of the cytotoxic agents and MDR modulators as well as competition experiments described in the text, seven binding sites for P-glycoprotein are proposed. Arrows indicate positive or negative communication between these sites. 